\title{
National Survey of USDA Field Staff on Climate and Weather
}

Results from a survey of Natural Resources Conservation Service and Farm Service

\section{Agency Employees}

Report Date: April 2018

\section{Prepared by:}

Sarah Wiener, USDA Forest Service

Gabrielle E. Roesch-McNally, USDA Forest Service

Rachel E. Schattman, USDA Forest Service; University of Vermont

Acknowledgements:

Rich Iovanna, USDA Farm Service Agency

Mary Carey, USDA Farm Service Agency

Dan Lawson, USDA Natural Resources Conservation Service, USDA Climate Hubs

Mike Wilson, USDA Natural Resources Conservation Service

Meredith T. Niles, University of Vermont

Lynn G. Knight, USDA Natural Resources Conservation Service

Daniel Dostie, USDA Natural Resources Conservation Service

David Y. Hollinger, USDA Forest Service

Rachel Steele, USDA Climate Hubs

Suggested citation:

Wiener, S., Roesch-McNally, G.E., and Schattman, R.E. (2018). National survey of USDA Field Staff on Climate and Weather; Results from a survey of Natural Resources Conservation Service and Farm Service Agency Employees. Washington, DC: USDA Climate Hubs.

\section{USDA Climate Hubs}

\section{U.S. DEPARTMENT OF AGRICULTURE}
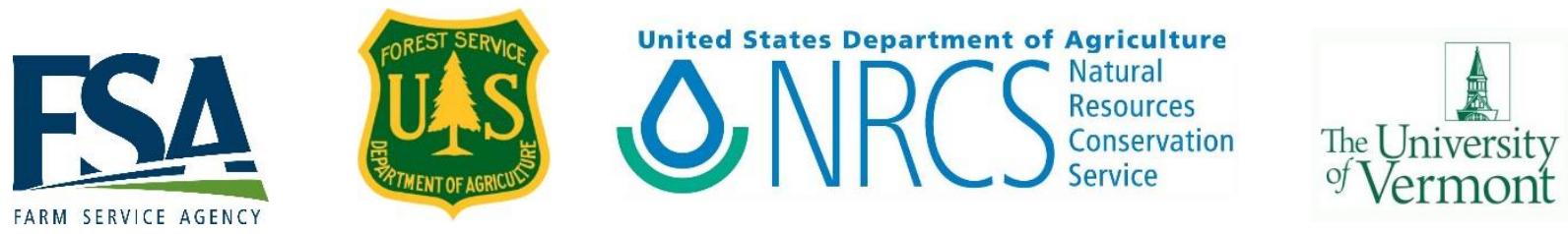


\section{NATIONAL SURVEY ON CLIMATE AND WEATHER}

Prepared by Rachel Schattman (USDA Northeast Climate Hub), Sarah Wiener

(USDA Southeast Climate Hub), and Gabrielle Roesch-McNally (USDA Northwest

Climate Hub)

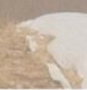

\section{Key Points}

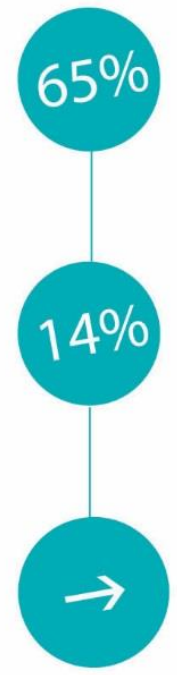

of FSA employees who responded to the survey believe that it is important for producers to adapt to climate change to ensure the long-term viability of U.S. agriculture.

of respondents agreed or strongly agreed that they personally have the knowledge to help producers deal with weather-related threats.

Opportunities for future collaboration between FSA and other agency partners include outreach and education on climateand weather-related issues by linking them to existing programs that help producers to reduce climate-related risks.

\section{Project Overview}

In November/December of 2016, a survey collaboratively designed by the USDA Climate Hubs, FSA, and the University of Vermont was administered to capture FSA field staffs' beliefs and attitudes related to climate change and potential impacts, as well as their perceptions about the risk that weather variability poses for U.S. farmers. The survey also investigated the types of climate and weather tools FSA staff currently use in their work with land managers. Over 10,000 FSA staff throughout the U.S. were contacted for the survey; in total 4,621 FSA staff responded (response rate $=42 \%$, calculated using the RR4 method of the American Association for Public Opinion Research, AAPOR).

It is important for producers to adapt to climate change to ensure the long-term success of U.S. agriculture

Producers should take addional steps to protect their operations from increased weather variability

Producers should do more to reduce greenhouse gas emissions from their farm operations

In my current role, I should help producers to prepare for increased weather variability

Climate change is not a big issue because human ingenuity will enable producers to adapt to changes

I have the knowledge to help producers deal with any weather-related threats to the viability of their farm operations

$0 \%$

$10 \%$

$20 \%$

$30 \%$

$40 \%$

$50 \%$

$60 \%$

$70 \%$

$80 \%$

$90 \%$

$100 \%$

घtongly agree $\quad$ Agree $\quad$ Neither agree nor disagree $\quad$ Disagree $\quad$ Strongly disagree

Figure 1: FSA respondents' percent agreement with climate and weather statements $(n=3,572)$.

\section{USDA Climate Hubs}




\section{Survey Result Highlights}

FSA employees reported using weather and climate resources when discussing the following topics with producers: crop rotations/field assignments ( $32 \%$ of respondents); crop/ variety choices (35\%); purchasing crop insurance or enrolling in the Noninsured Crop Disaster Assistance Program (NAP) (51\%); and planting or harvest schedules $(42 \%)$. One third $(33 \%)$ of respondents do not use historical weather trends and/or forecasts for any of the topics listed in the survey. Respondents do not use or are not familiar with many of the weather-related resources listed in the survey, with the exception of U.S. Drought Monitor (74\% use this resource) and livestock heat indices ( $42 \%$ use these resources, which are often state-specific). Nearly one-third of respondents report using the Farmers' Almanac as a weather resource in their professional service.

When asked to rank level of concern for 18 different climate and weather effects, the majority of states and territories (40 out of 53) reported the most concern with longer dry periods and drought (Figure 2). Most respondents agree or strongly agree that there is increasing variable and unusual weather in their areas (59\%), and that to cope with increasing climate variability, farming practices will need to change (54\%). Additionally, nearly half (42\%) agree or strongly agree that extreme weather events in recent years have affected the long-term management goals of producers, and that there is increased need for FSA's programs in their service area due to changing weather patterns (42\%). One-third agree or strongly agree that they would like climate or weather forecasts to inform the services they provide in the future, while $61 \%$ agree or strongly agree that producers use climate information when making farm-related decisions.

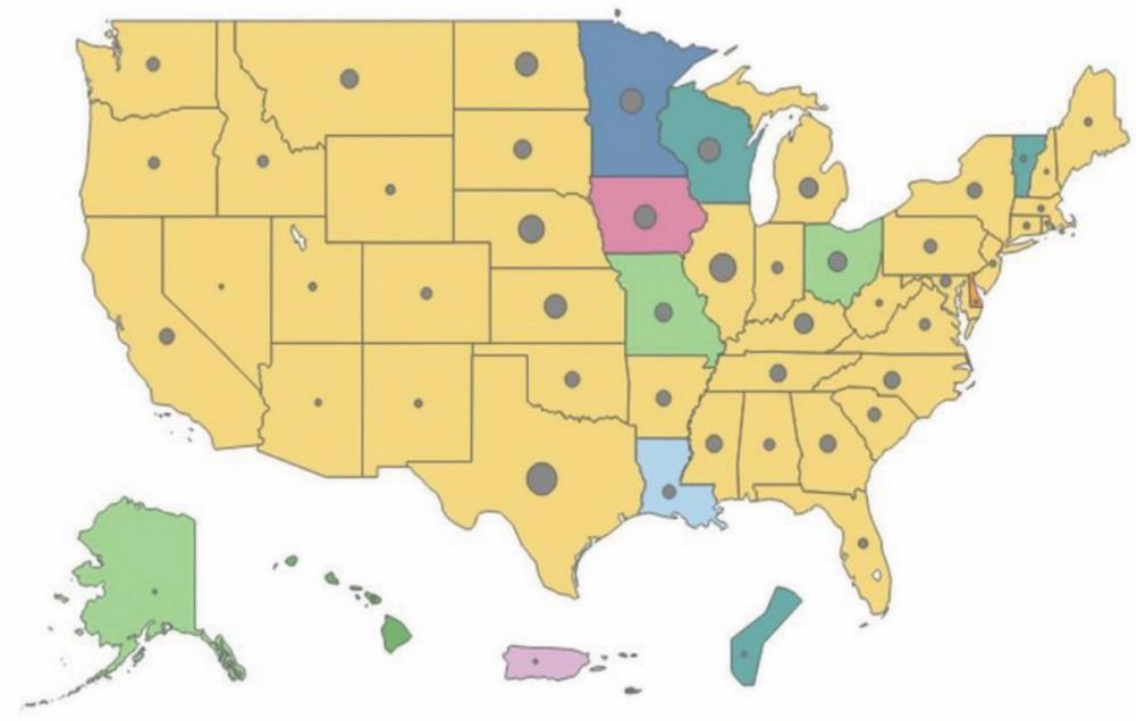

Figure 2: Most common climate or weather concern of FSA field staff per state $(n=3,571)$. Eighteen climate and weather trends were rated on a Likert scale ( 1 =not concerned; 2 =slightly concerned; 3 =concerned; and 4=very concerned).
Adapting to changing weather conditions is something the majority of respondents agree is important (Figure 1). Over half of respondents agreed or strongly agreed that producers should take additional steps to protect their operations from increased weather variability (61\%), and that it is important for producers to adapt to climate change to ensure the long-term viability of U.S. agriculture (65\%). However, only $14 \%$ agree or strongly that they personally have the knowledge to help producers deal with weather-related threats.

\section{Discussion}

The mission of the Climate Hubs is to develop and deliver science-based, region-specific information and technologies, with USDA agencies and partners, to agricultural and natural resource managers that enable climate-informed decision-making, and to provide access to assistance to implement those decisions. Based on the findings from this national level survey, we have identified three potential areas of future collaboration between the Climate Hubs and FSA: (1) provide training and support for FSA employees to work with and understand weather and climate data, tools, and resources; (2) better integrate specific weather and climate tools into specific FSA program areas; (3) hone outreach and education on climate- and weather-related issues by linking them to existing programs that help producers to reduce climate-related risks on farm (such as the Conservation Reserve Enhancement Program).

\section{Count of Respondents}

1

- 100

200

300

350

\section{Climate or Weather Concern}

Excessive moisture

Increased flooding

Increased heat stress on crops

Increased incidence of hurricanes or tropical depressions

Increased insect pressure \& higher

incidence of crop disease (tie)

Increased soil erosion

Increased weed pressure

Longer dry periods and droughts

More frequent extreme rain events

Figures by Sarah Wiener. Photography credits: Rachel Schattman 
Prepared by Gabrielle Roesch-McNally (USDA Northwest Climate Húb), Sarah Wiener (USDA Southeast Climate Hub), and Rachel Schattman (USDA Northeast Climate Hub)

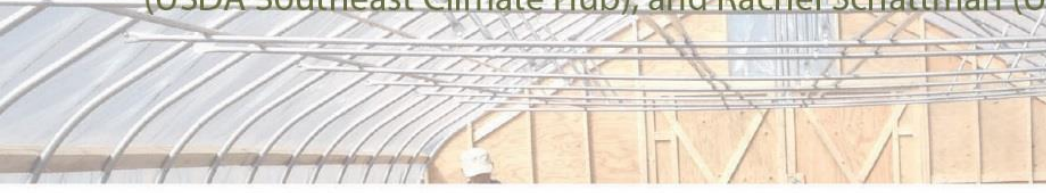

\section{Key Points}

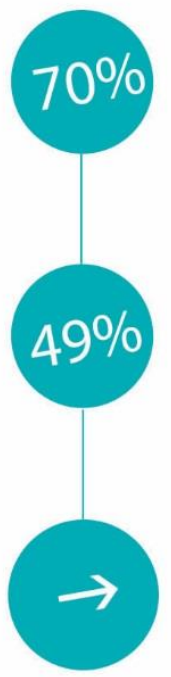

of NRCS employees who responded to the survey believe that it is important for producers to adapt to climate change to ensure the long-term viability of U.S. agriculture.

of the respondents reported that they are confident in their ability to apply weather forecasts and information to the services that they provide.

Opportunities for future collaboration between NRCS and other agency partners include outreach and education on climate and weather-related issues by linking them to existing programs that help producers to reduce climate-related risks.

\section{Project Overview}

June 2017
The USDA Climate Hubs, NRCS, and the University of Vermont collaboratively designed a survey, administered in February/March 2017, to capture NRCS field staff views and understanding related to climate change, weather variability, and potential impacts on agriculture. The survey also addressed NRCS employees' perceptions about the risk that weather variability poses for U.S. farmers. Over 8,000 NRCS employees nationwide were targeted and 1,893 NRCS staff completed the survey (response rate $=22.3 \%$, calculated using the RR4 method of the American Association for Public Opinion Research, AAPOR). The three main positions held by respondents were District Conservationist (25\%), Soil Conservationist (19\%) and Soil Conservation/Engineering Technician (16\%). The majority work at NRCS Service Centers (74\%), followed by Area Offices (12\%) and State Offices (10\%).

Current weather conditions

\section{1-7 day forecasts}

Historical weather trends

8-14 day outlooks

Monthly or seasonal outlooks

Weather data for the past 12 months

Annual or longer term outlooks

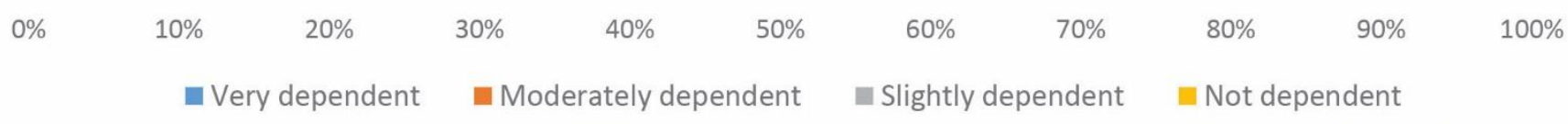

Figure 1: NRCS respondents reported dependency on weather and climate information

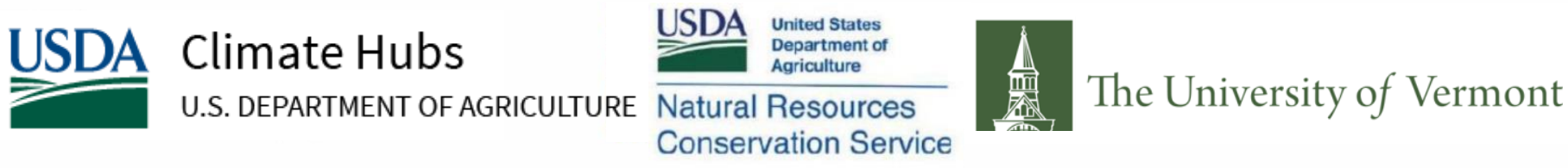




\section{Survey Result Highlights}

NRCS employees most commonly integrate daily, weekly, or seasonal weather forecast information into guidance to clients for the following topics: in-field conservation practices (73\%), grazing and forage management $(71 \%)$, tillage $(67 \%)$, livestock management systems (64\%), and on-farm water management (60\%). Survey respondents are most dependent on current and short-term weather information (1-7 day forecasts), and much less dependent on monthly and seasonal outlooks or annual and longer-term outlooks (Figure 1). Of 12 weather-related tools and resources, respondents most frequently use the U.S. Drought Monitor (68\%), growing degree day tools (41\%), and evapo-transpiration indices (38\%).

NRCS employees reported regularly working with producers who have experienced adverse events/conditions in the past few years largely tied to extreme or variable weather events. Climate or weather trends reported to be the most concerning in each state vary (Figure 2 ). The majority of states and territories (29) reported producers are most concerned with longer dry periods/drought, followed by increased soil erosion (6), increased weed pressure (4), higher incidences of tree pathogens (4), and higher incidence of wildfire (3).

Most respondents (65\%) agree or strongly agree that there is increasing variable and unusual weather in their areas, and that to cope with increasing climate variability farming practices will need to change ( $70 \%$ agree or strongly agree). More than half $(52 \%)$ agree or strongly agree that extreme weather events in recent years have affected the long-term management goals of producers in their service area. Most respondents (65\%) agree or strongly agree that producers use climate information when making farm-related decisions and $41 \%$ agree or strongly agree that there is an increased need for NRCS's programs in their service area due to changing weather patterns. The majority agree or strongly agree (66\%) that they would like climate or weather forecasts to inform the services they provide in the future. While $53 \%$ of respondents believe that assisting producers to prepare for weather variability is part of their job, only $35 \%$ agree or strongly agree that they have the knowledge and technical skill to help producers deal with those threats.

\section{Discussion}

The mission of the Climate Hubs is to work with USDA agencies and partners to develop and deliver science-based, region-specific information and technologies to agricultural and natural resource managers, enabling climate-informed decision-making, and assisting in the implementation of those decisions. As a result of this survey analysis, we have identified three areas of potential collaboration between NRCS and the Climate Hubs: (1) providing greater access to and awareness of weather and climate related tools; (2) providing educational resources on the topic of climate science and global weather dynamics; (3) developing outreach and education messaging through the NRCS Public Affairs Division on climate and weather-related issues. Messaging could be linked to existing NRCS efforts, such as the Soil Health Initiative and to conservation practices that reduce risks, increase productivity, and build resilience across production sectors.

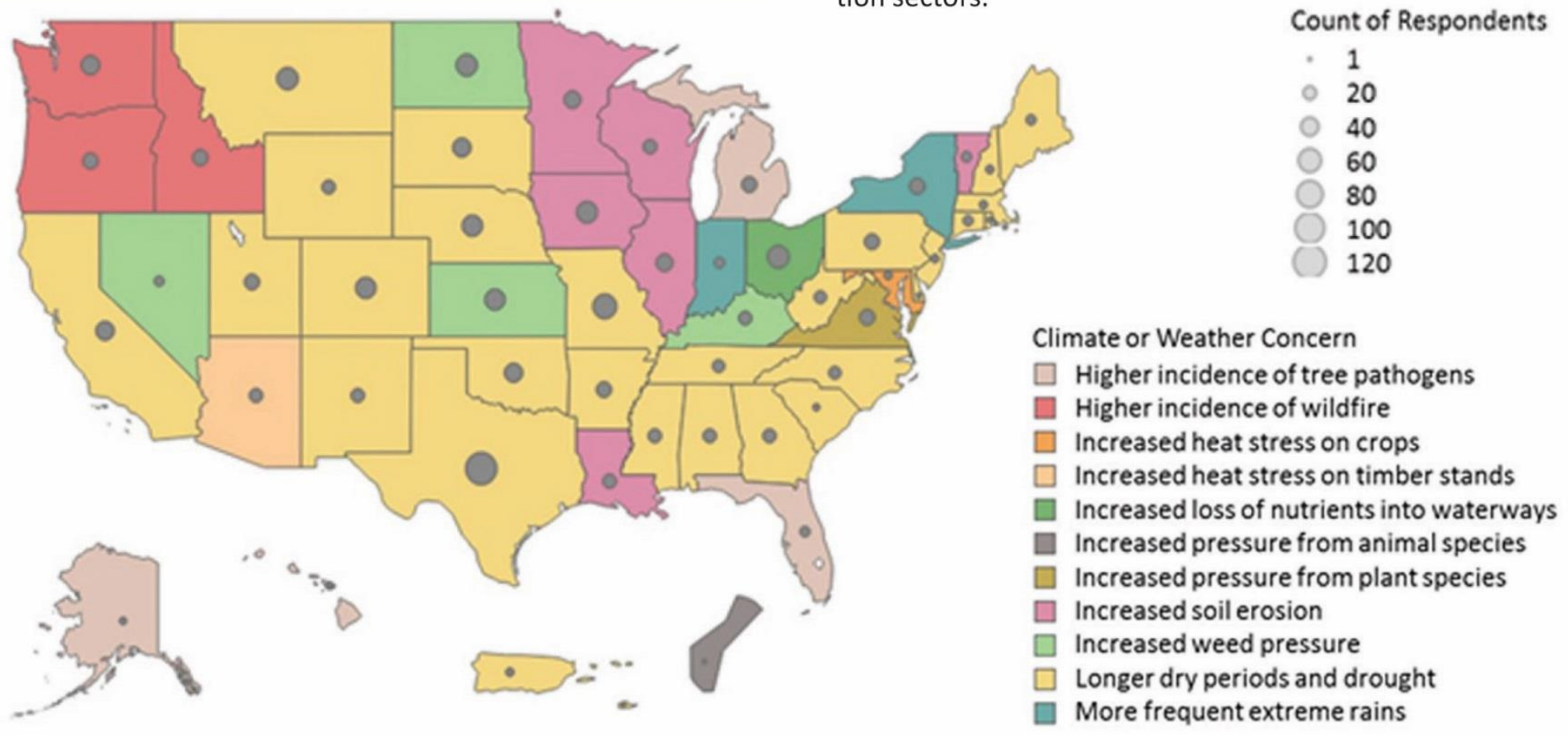

Figure 2: Most common climate or weather concern of NRCS field staff per state $(n=1,376)$. Twenty-six climate and weather trends were rated on a Likert scale (1=not concerned; $2=$ slightly concerned; 3 =concerned; and 4=very concerned 


\section{Contents}

Introduction




\section{Introduction}

Climate change adaptation and mitigation are issues critical to the long-term success of land management in the United States (Lal et al. 2011). USDA Natural Resources Conservation Service (NRCS) and Farm Service Agency (FSA) staff are in a unique position to support farmers, ranchers, and foresters to effectively adapt to changing weather patterns and climatic conditions through indemnities, low cost farm loans, conservation programs, and conservation technical assistance. Additionally, both agencies house a large number of employees that are in frequent contact with land managers through administration of these programs. To effectively provide this type of technical support to land managers, field staff must possess accurate information about climate change and weather variability, and applied knowledge about how these stressors are most likely to impact their clients.

If programmatic efforts can be made to improve climate-related technical assistance and support to NRCS and FSA clients, we must first understand (a) the level of knowledge about climate change that NRCS and FSA field staff possess, (b) the degree to which those field staff are comfortable or confident supporting farmers and ranchers on climate resiliency, and (c) the climate and weather stressors and related impacts about which service providers are most concerned. Once a baseline of these three variables is established, targeted professional development opportunities can be made available to ensure that field staff are poised to serve their clients in the context of more variable and extreme weather events driven by climate change.

To these aims, two surveys were collaboratively designed and administered by the USDA Climate Hubs, NRCS, FSA, and the University of Vermont to capture NRCS and FSA employee beliefs and attitudes related to climate change causes, potential impacts, and perceptions of climate-related risks specific to land management. Additional survey questions explored the types of climate and weather tools staff currently use in their work with land managers. The surveys were administered in November and December of 2016 (FSA), and February and March of 2017 (NRCS).

\section{Methods}

The surveys (see Appendices B and C) were designed and administered using the Dillman Tailored Design Method (Dillman et al. 2008), and were based on a template developed for the Useful to Useable project (https://mygeohub.org/groups/u2u) (See Prokopy et al. 2013). While the FSA and NRCS surveys followed the same themes and contained many identical questions, some questions and sub-questions were adapted to reflect the unique missions of the programs in those respective agencies. Human subjects research approval was granted by the Institutional Review Board at University of Vermont and the survey complies with exempt requirements under human subject research rules (UVM IRB Protocol Exemption Certification: CHRBSS: 170254). NRCS State Conservationists received letters from NRCS Deputy Chiefs, and FSA Deputy Administrators of Field Offices (DAFOs) were alerted to the survey via conference call. Employees were then sent an initial invitation to take the voluntary survey by State Conservationists and DAFOs, followed by three additional survey reminders sent each week during the course of a month. 
Over 8,000 NRCS employees and 10,000 FSA employees throughout the U.S. were targeted for the survey. Employee contact information was gathered from publicly available service center directories. Employees with position titles that implied they did not work with land managers directly were filtered out from the final list of target respondents. The process of survey sample refinement was informed by both FSA and NRCS staff who have in-depth knowledge of their respective agencies. In total 4,621 FSA employees and 1,893 NRCS employees responded to the survey, resulting in response rates of $43 \%$ and $22 \%^{1}$, respectively. The results of a non-response bias test suggests that there are few significant differences between survey respondents and nonrespondents for both FSA and NRCS employees. However, the sample of NRCS respondents was slightly older than the target population of NRCS employees. As with all survey analysis, it may be that there are factors that influence response bias that are not accounted for. However, the results from this survey provide robust information on the challenges and opportunities associated with presenting weather and climate-related information to agency employees.

Although job titles were filtered to exclude those who do not work directly with land managers, respondents were also asked if they work directly with land managers at the beginning of the survey. For FSA and NRCS, 92\% and $86 \%$ of respondents, respectively, indicated that they work directly with land managers. The results presented in the remainder of this report only include those who selected that they work directly with land managers.

\section{Results}

\section{Respondent occupational highlights}

Respondents from both agencies most commonly resided in county offices (FSA 95\%; NRCS $74 \%$; tables for this section can be found in Appendix A). The most frequent position descriptions held by NRCS respondents were District Conservationist (25\%) and Soil Conservationist (19\%), while FSA respondents most commonly reported being Program Technicians (56\%) and County Executive Directors (22\%). NRCS respondents were also asked about the sectors in which they work. The majority of NRCS respondents work directly with farmers $(83 \%)$, followed by ranchers $(51 \%)$, and forest landowners $(44 \%)^{2}$. However, when asked in what sector they spend the majority of their time, $100 \%$ indicated that agriculture was their primary focus.

Respondents from both agencies were most likely to report highest participation in their programs by farms and ranches between 100-999 acres (FSA 54\%; NRCS 47\%). However, NRCS reported greater participation from small farms, defined as grossing less than $\$ 350 \mathrm{k}$ (48\%), while FSA reported highest participation from midsize farms, defined as grossing \$350k$\$ 999,999$ (49\%). Of those NRCS employees who reported working with forest landowners, the majority of participation comes from small-scale operations that are between 20 and 199 acres $(66 \%)$. FSA respondents reported grains, oilseeds, dry beans, and dry peas as the most common crop grown by the producers they serve (86\%), followed by cattle and calves $(80 \%)$, and alfalfa and other hay (71\%). NRCS respondents reported that the majority of their clients produce cattle

\footnotetext{
${ }^{1}$ Calculated using AAOPR4 response rate calculator

${ }^{2}$ Percentages exceed $100 \%$ because participants were asked to choose all that apply.
} 
and calves (83\%), hay, forages and silages (70\%), and grains, oilseeds, dry beans and dry peas (64\%). Respondents were instructed to select all options that apply for this question.

Fewer than half of respondents reported operating, owning or having a financial stake in a farm or ranch (FSA 43\%; NRCS 33\%), and most of those employees reported that they manage, own, or invest in small farms, defined as gross sales less than $\$ 350,000$ (FSA 75\%; NRCS 83\%). Fewer employees reported owning or having financial stake in a forest (NRCS 15\%; this question was not asked of FSA respondents), and the majority of those respondents (87\%) owned or had a stake in a small operation (under 2 million board feet per year). Only $3 \%$ of FSA respondents reported being a member of an FSA county or state committee.

\section{Respondent demographic highlights}

Most FSA respondents were white (86\%), non-Hispanic (87\%), and female (68\%; tables for this section can be found in Appendix A). Most NRCS respondents were white (75\%), non-Hispanic $(71 \%)$, and male $(63 \%)$. This is reflective of demographics for staff of both agencies. The average length of time employees have worked for their respective agencies and for USDA was 17 years. Slightly more than half of FSA respondents have completed either a 4-year college degree $(46 \%)$ or a graduate degree $(8 \%)$. The majority of NRCS respondents have completed a 4 -year college degree (65\%), with an additional $24 \%$ having completed a graduate degree. NRCS employees were also asked about their degree subject, and the most common responses were natural resource management $(31 \%)$ and agronomy $(21 \%)$.

\section{Use of climate and weather tools}

To understand how field staff use climate and weather resources, respondents were asked to report the types of resources they use, which they are most familiar with, and the programmatic context in which they applied these resources. The most common topics that were informed by weather trends and/or forecasts for FSA employees were crop yields (55\%), purchasing crop insurance or NAP (Non-insured Crop Disaster Assistance Program; 51\%), and planting or harvest schedules (42\%; Figure 1). The top three topics for NRCS were in-field conservation practices $(73 \%)$, grazing and forage management (71\%), and tillage decisions (66\%; Figure 2). Overall, 33\% of FSA respondents and $8 \%$ of NRCS respondents do not use historical weather trends and/or forecasts for any of the topic options listed in the survey.

Respondents were also asked about their dependence on climate and weather information from a temporal perspective. Again, NRCS employees reported greater dependence overall on the suite of information included in this survey question than FSA employees (Figures 3 and 4). Both FSA and NRCS employees most commonly reported being very or moderately dependent on information related to current weather conditions (FSA 55\%; NRCS 70\%) with dependence diminishing with longer-term forecasts. Respondents from both agencies reported being very or moderately dependent on monthly or seasonal outlooks (FSA 37\%; NRCS 50\%) and annual or longer term outlooks (FSA 29\%; NRCS 46\%) much less frequently. Regarding historical data, NRCS respondents were more often very or moderately dependent on historical weather trends (57\%), while FSA employees were more dependent on weather data from the past 12 months $(40 \%)$. 
Respondents do not use or are not familiar with many of the weather-related resources listed in the survey (Table 1). The U.S. Drought Monitor is the only tool that is used by over half of respondents in both agencies (FSA 74\%; NRCS 66\%). Nearly one-third of respondents from both agencies report using the Farmers' Almanac as a weather resource (FSA 30\%; NRCS 28\%). Though the Farmers' Almanac contains historical weather data, it is not regarded as an accurate source of weather forecasts (Masters, 2013; Samenow, 2016).

Table 1: Responses to, "Do you use the following weather-related resource?" Question adapted from Prokopy et al. 2013.

\begin{tabular}{|c|c|c|c|c|c|}
\hline & Agency & Rank & Use & Don't use & Not familiar with \\
\hline \multirow{2}{*}{ U.S. Drought Monitor or Outlook } & FSA & 1 & $74 \%$ & $18 \%$ & $8 \%$ \\
\hline & NRCS & 1 & $66 \%$ & $27 \%$ & $6 \%$ \\
\hline Livestock Heat Index & FSA & 2 & $42 \%$ & $38 \%$ & $20 \%$ \\
\hline Cattle Heat Stress Forecast & NRCS & 6 & $18 \%$ & $60 \%$ & $23 \%$ \\
\hline \multirow{2}{*}{ Growing Degree Day Tools } & FSA & 5 & $18 \%$ & $49 \%$ & $34 \%$ \\
\hline & NRCS & 2 & $41 \%$ & $42 \%$ & $17 \%$ \\
\hline \multirow{2}{*}{ Farmer's Almanac } & FSA & 3 & $30 \%$ & $60 \%$ & $10 \%$ \\
\hline & NRCS & 5 & $28 \%$ & $69 \%$ & $3 \%$ \\
\hline \multirow{2}{*}{$\begin{array}{l}\text { Satellite Data/Indices of Water or } \\
\text { Soil Nitrogen Status, Precip or Temp }\end{array}$} & FSA & 4 & $22 \%$ & $49 \%$ & $30 \%$ \\
\hline & NRCS & 4 & $30 \%$ & $45 \%$ & $26 \%$ \\
\hline \multirow{2}{*}{ Evapotranspiration Index } & FSA & 9 & $4 \%$ & $51 \%$ & $45 \%$ \\
\hline & NRCS & 3 & $39 \%$ & $43 \%$ & $18 \%$ \\
\hline \multirow{2}{*}{ Crop Disease Forecasts } & FSA & 6 & $15 \%$ & $52 \%$ & $32 \%$ \\
\hline & NRCS & 8 & $16 \%$ & $53 \%$ & $31 \%$ \\
\hline \multirow{2}{*}{ Insect Forecasts } & FSA & 7 & $13 \%$ & $53 \%$ & $35 \%$ \\
\hline & NRCS & 7 & $17 \%$ & $52 \%$ & $31 \%$ \\
\hline \multirow{2}{*}{ Forage Dry Down Index } & FSA & 8 & $8 \%$ & $55 \%$ & $37 \%$ \\
\hline & NRCS & 10 & $11 \%$ & $57 \%$ & $32 \%$ \\
\hline USDA Climate Hubs Tool Shed & NRCS & 9 & $13 \%$ & $48 \%$ & $39 \%$ \\
\hline COMET-Farm & NRCS & 11 & $8 \%$ & $52 \%$ & $40 \%$ \\
\hline $\begin{array}{l}\text { Adaptation workbook for forest } \\
\text { management }\end{array}$ & NRCS & 12 & $7 \%$ & $49 \%$ & $44 \%$ \\
\hline
\end{tabular}




\section{FSA - Do you consider historical weather trends and/or forecasts when you discuss... $(n=3,580)$}

Crop yields

Purchasing crop insurance or NAP

Planting or harvest schedule

Market informatio

Crop and commodity storage

Crop and/or variety choice

Crop rotations and field assignments

Tillage decision

Fertilizer purchase and application

Irrigation systems

Livestock purchases

Pesticide purchase and application

Agriculture drainage system

Integrated pest management practices

Fuel purchases

Livestock genetics
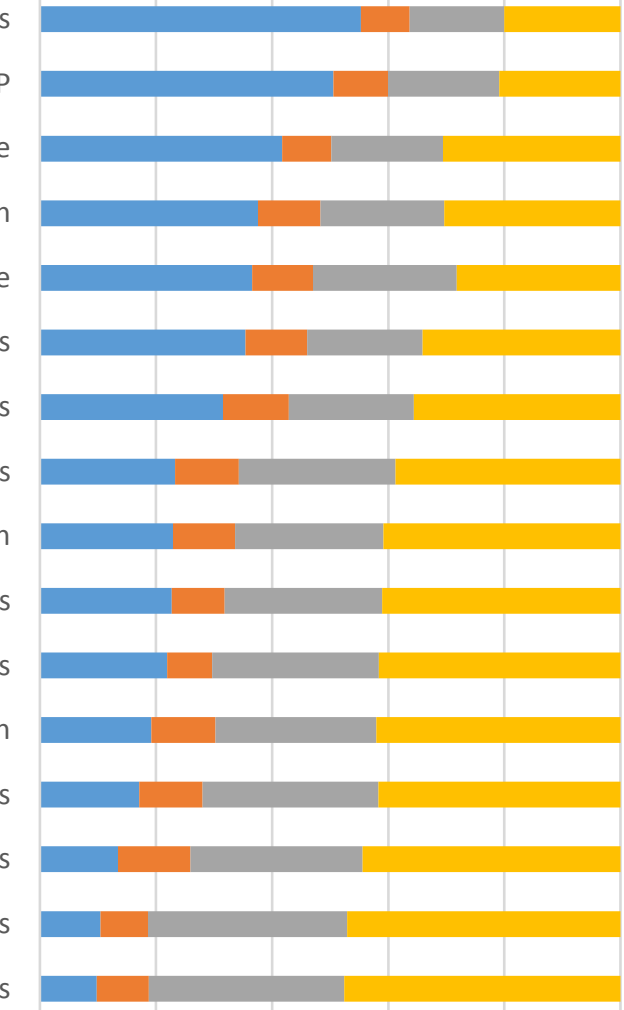

$\begin{array}{llllll}0 \% & 20 \% & 40 \% & 60 \% & 80 \% & 100 \%\end{array}$

- Yes, I do

- No, but I would if I had better information

No, I don't

I don't discuss these topics with producers

Figure 1: FSA responses to, "Do you consider historical weather trends and/or forecasts when you discuss..." Questions adapted from Prokopy et al. 2013.
NRCS - Do you consider historical weather trends and/or forecasts when you discuss... $(n=1,316)$

In-field conservation practices Grazing and forage management Tillage decisions

Livestock management

On-farm water management systems

Planting or harvest schedule of crops

Crop and/or variety choices

Manure management

Fertilizer purchase and application

Non-field conservation practices

Manure management systems

Planting or harvest schedule of timber

Integrated pest management practices

Pesticide purchase and application

Edge-of-field conservation practices

Energy/fuel efficiency

Livestock breed selection
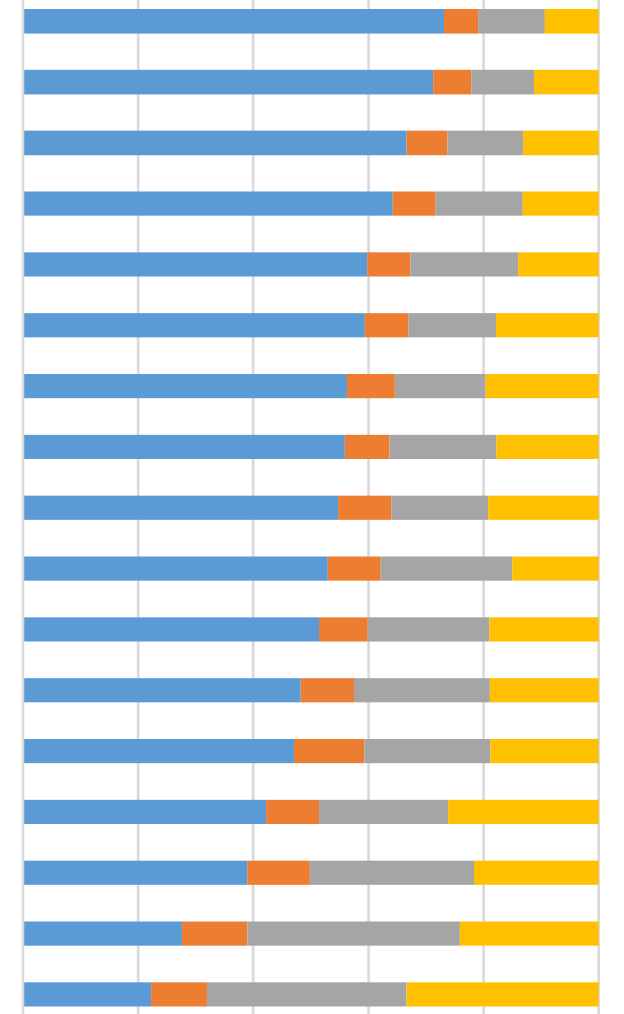

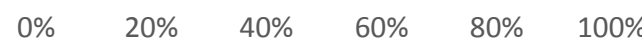

- Yes, I do

No, but I would if I had better information

No, I don't

I I don't discuss these decisions with producers

Figure 2: NRCS responses to, "Do you consider historical weather trends and/or forecasts when you discuss..." Questions adapted from Prokopy et al. 2013. 
FSA - How dependent are you on the following types of weather information to do your job? $(n=3,587)$

Current weather conditions 1-7 day forecasts

Weather data past 12 months 8-14 day forecasts

Monthly or seasonal outlooks

Annual or longer term outlooks Historical weather trends
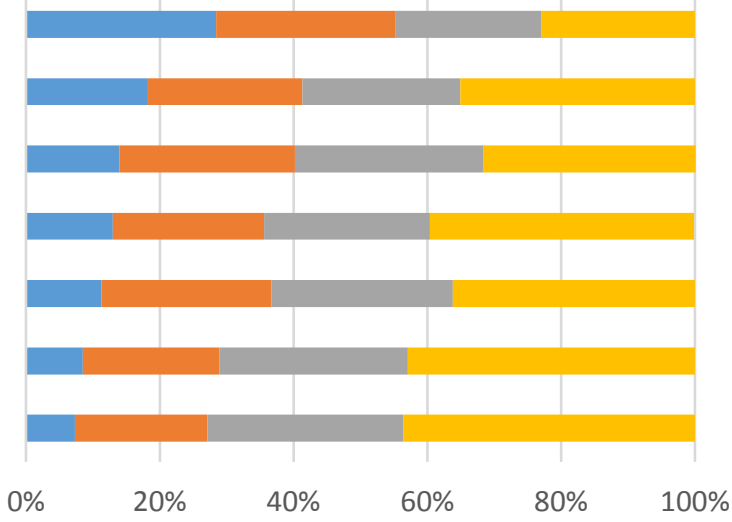

Very dependent $\square$ Moderately dependent $\quad$ Slightly dependent $\quad$ Not dependent Figure 3: Dependence on weather information in job of FSA respondents. Questions adapted from Prokopy et al. 2013.
NRCS - How dependent are you on the following types of weather information to do your job? $(n=1,554)$

Current weather conditions

1-7 day forecasts

Historical weather trends 8-14 day outlooks

Monthly or seasonal outlooks

Weather data for the past 12 months

Annual or longer term outlooks

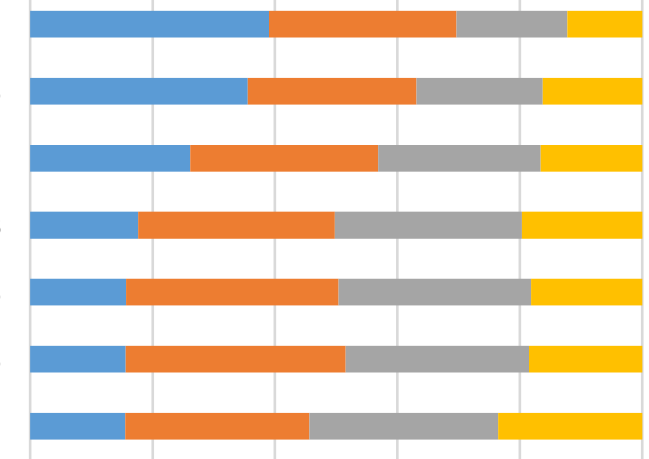

$\begin{array}{llllll}0 & 20 \% & 40 \% & 60 \% & 80 \% & 100 \%\end{array}$

$\square$ Very dependent $\square$ Moderately dependent $\square$ Slightly dependent $\square$ Not dependent

Figure 4: Dependence on weather information in job of NRCS respondents. Questions adapted from Prokopy et al. 2013. 


\section{Perspectives on climate change}

A strong majority of respondents from both agencies believe that climate change is occurring (FSA 77\%; NRCS 81\%; Figure 5), but there is disagreement about what is causing climate change. The most common answer from both agencies is that it is caused by a mix of natural and human causes (FSA 46\%; NRCS 36\%), while others believe it is mostly human caused (FSA $13 \%$; NRCS $27 \%$ ), or mostly naturally caused (FSA 18\%; NRCS 18\%). Some do not think there is sufficient evidence to say whether climate change is occurring or not (FSA 21\%; NRCS 17\%), and a small proportion do not think climate change is occurring at all (FSA 3\%; NRCS $2 \%$ ).

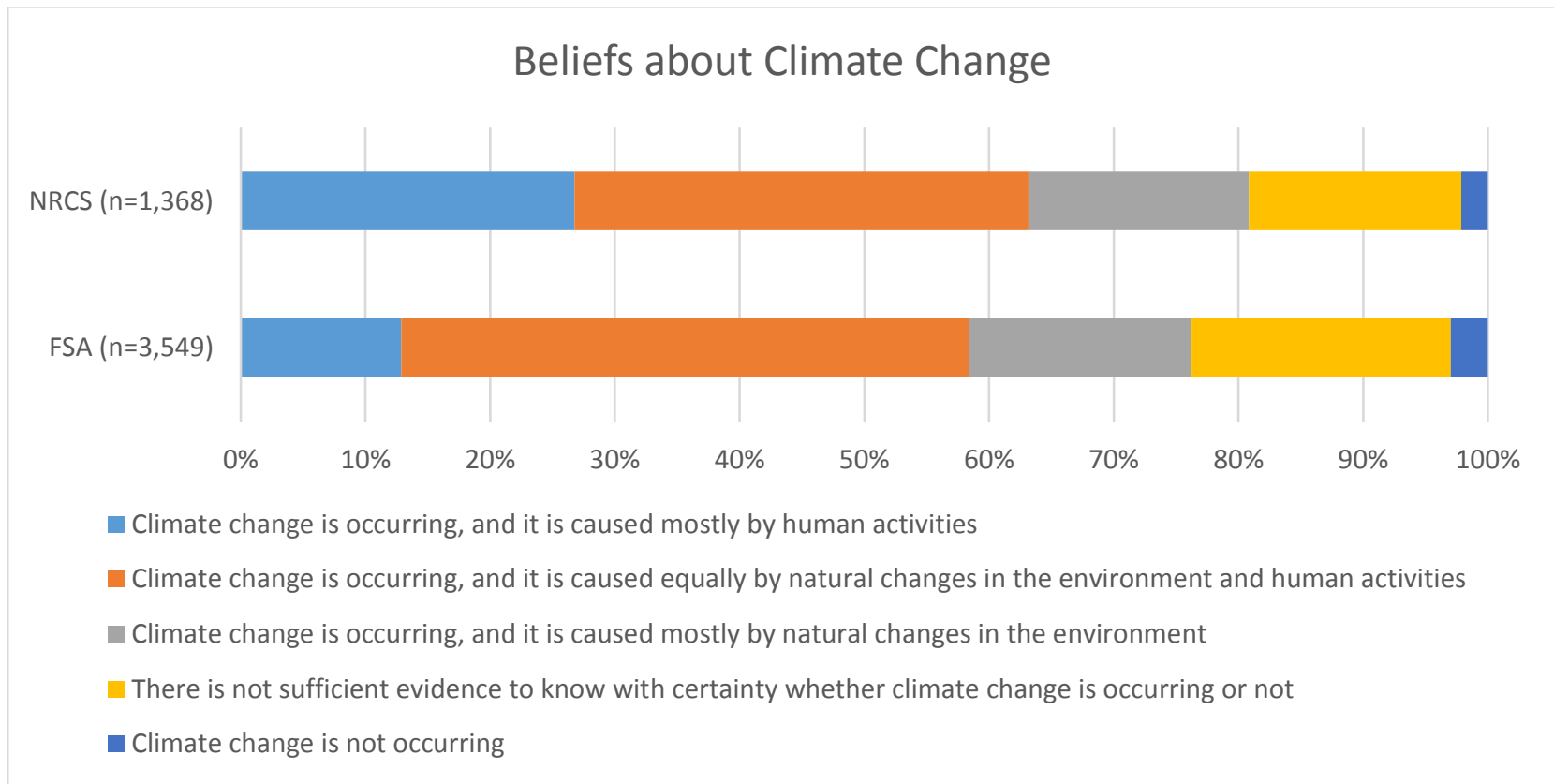

Figure 5: Respondent beliefs about climate change. Question adapted from Prokopy et al. 2013. 


\section{Attitudes regarding climate and weather risks}

Respondents were asked to indicate their level of agreement with several statements (Tables 2-4) related to climate and weather, and related impacts on producers, service provision, and agriculture in general, the results of which are described in the next three sub-sections. Statements on use of climate and weather data and comfort with these resources were also included in this same question format (statements adapted from Prokopy et al. 2013). Agreement was indicated on a five point Likert scale: (1) strongly disagree; (2) disagree; (3) neither agree nor disagree; (4) agree; (5) strongly agree. Though not included in the FSA survey, a distinction between weather and climate was added to the beginning of the NRCS survey. At the beginning of the NRCS survey, weather was defined as "changing conditions of the earth's atmosphere over short periods of time (e.g. minutes to months)," and climate was defined as "trends in the earth's atmosphere over relatively longer periods of time (e.g. decades to centuries)."

\section{Perspectives on land managers}

A majority of respondents from both agencies strongly agree or agree that weather has become more variable or unusual in the past five years (FSA 59\%; NRCS 65\%; Table 2), and to cope with increasing climate variability, a change in farming practices is important for long-term success (FSA 54\%; NRCS 67\%). However, fewer than half of respondents from both agencies strongly agree or agree that changes in weather patterns are currently hurting producers in their service areas (FSA 37\%; NRCS 38\%). Overall, NRCS respondents were more likely than FSA respondents to agree that weather is becoming increasingly variable, that extreme weather is affecting long-term management goals of land managers, and that farmers must adapt. Respondents from the two agencies were aligned in that they agree that producers are currently using climate information for decision making, that changes in weather patterns are hurting producers in their service area, and that farms that have not used their programs in the past will become more vulnerable going forward.

\section{Perspectives on service provision}

Over half of NRCS respondents strongly agree or agree that they want climate or weather forecasts to inform client decisions (63\%; Table 3); far fewer FSA respondents want climate or weather forecasts to inform the services they provide $^{3}(34 \%)$. However, far fewer respondents from both agencies reported confidence in their ability to apply weather forecasts and information in their services (FSA 26\%; NRCS 47\%). Overall, NRCS respondents were more confident in their ability to apply weather forecasts and information to their services and that other service providers consult with them, but there was greater agreement regarding whether or not there will be an increased need for each agency's programs due to changing weather patterns.

\section{Perspectives on climate and weather impacts}

Well over half of respondents from both agencies strongly agree or agree that it is important for producers to adapt to climate change to ensure long-term success of US agriculture (FSA 65\%;

\footnotetext{
${ }^{3}$ NRCS and FSA respondents were asked to indicate agreement with slightly different statements. NRCS employees were presented with the statement, "I would like climate or weather forecasts to inform the client decisions," while FSA respondents were presented with the statement, "I would like climate or weather forecasts to inform the services I provide."
} 
NRCS 72\%; Table 4). Similar responses were reported when the same question was asked about forestry (71\%) and rangeland (69\%), for those NRCS employees who report working directly with each of those types of land managers. Over half of respondents from both agencies also strongly agree or agree that producers should take additional steps to protect their operations from increased weather variability (FSA 61\%; NRCS 68\%). NRCS respondents were more likely than FSA respondents to believe that they personally should play a role in assisting producers in adapting their operations (FSA 29\%; NRCS 52\%). Regardless, a significant proportion from both agencies believe this to be a part of their job, but far fewer respondents believe they have the knowledge and technical skills to help producers deal with weather-related threats to their operations (FSA 14\%; NRCS 34\%).

Table 2: Agreement with statements about producers; ranked on a five point Likert scale: (1) strongly disagree; (2) disagree; (3) neither agree nor disagree; (4) agree; (5) strongly agree. Questions adapted from Prokopy et al. 2013.

\begin{tabular}{|c|c|c|c|c|c|c|}
\hline & Agency & Rank & Mean & $\begin{array}{l}\text { Std. } \\
\text { Dev. }\end{array}$ & $\mathrm{N}$ & $\begin{array}{l}\text { \% Strongly } \\
\text { Agree/Agree }\end{array}$ \\
\hline \multirow{2}{*}{$\begin{array}{l}\text { In the past } 5 \text { years, I have noticed more } \\
\text { variable/unusual weather in my area }\end{array}$} & FSA & 2 & 3.55 & 0.98 & 3624 & $59 \%$ \\
\hline & NRCS & 2 & 3.79 & 1.12 & 1373 & $65 \%$ \\
\hline \multirow{2}{*}{$\begin{array}{l}\text { To cope with increasing climate variability, changing } \\
\text { farming practices is important for the long-term } \\
\text { success of producers in my service area }\end{array}$} & FSA & 3 & 3.52 & 0.92 & 3615 & $54 \%$ \\
\hline & NRCS & 1 & 3.84 & 1.09 & 1361 & $67 \%$ \\
\hline \multirow{2}{*}{$\begin{array}{l}\text { Producers use climate information when making farm- } \\
\text { related decisions }\end{array}$} & FSA & 1 & 3.65 & 0.90 & 3591 & $61 \%$ \\
\hline & NRCS & 4 & 3.66 & 0.94 & 1361 & $63 \%$ \\
\hline \multirow{2}{*}{$\begin{array}{l}\text { Extreme weather events in recent years have affected } \\
\text { the long-term management goals of producers in my } \\
\text { service area }\end{array}$} & FSA & 4 & 3.28 & 0.96 & 3609 & $42 \%$ \\
\hline & NRCS & 6 & 3.45 & 1.02 & 1365 & $50 \%$ \\
\hline \multirow{2}{*}{$\begin{array}{l}\text { Changes in weather patterns are hurting the producers } \\
\text { in my service area }\end{array}$} & FSA & 6 & 3.21 & 0.98 & 3619 & $37 \%$ \\
\hline & NRCS & 7 & 3.26 & 1.06 & 1367 & $38 \%$ \\
\hline \multirow{2}{*}{$\begin{array}{l}\text { Farms in my service area that historically have not had } \\
\text { an interest or need for FSA/NRCS's programs are or } \\
\text { will become more vulnerable moving forward }\end{array}$} & FSA & 5 & 3.25 & 0.94 & 3603 & $40 \%$ \\
\hline & NRCS & 8 & 3.24 & 1.03 & 1363 & $40 \%$ \\
\hline \multirow{2}{*}{$\begin{array}{l}\text { Producers in my service area have suffered due to } \\
\text { inaccurate weather information in the past }\end{array}$} & FSA & 7 & 3.04 & 0.88 & 3611 & $26 \%$ \\
\hline & NRCS & 9 & 3.24 & 0.90 & 1362 & $33 \%$ \\
\hline $\begin{array}{l}\text { Accurate or near-accurate weather information has } \\
\text { benefitted producers in my service area in the past }\end{array}$ & NRCS & 3 & 3.70 & 0.82 & 1372 & $64 \%$ \\
\hline $\begin{array}{l}\text { To cope with increasing climate variability, changing } \\
\text { forestry practices is important for the long-term } \\
\text { success of the producers in my service area }\end{array}$ & NRCS & 5 & 3.62 & 1.11 & 703 & $56 \%$ \\
\hline $\begin{array}{l}\text { Changes in weather patterns are benefiting the } \\
\text { producers in my service area }\end{array}$ & NRCS & 10 & 2.73 & 0.84 & 1365 & $13 \%$ \\
\hline
\end{tabular}


Table 3: Agreement with statements about service provision; ranked on a five point Likert scale: (1) strongly disagree; (2) disagree; (3) neither agree nor disagree; (4) agree; (5) strongly agree. Questions Adapted from Prokopy et al. 2013.

\begin{tabular}{|c|c|c|c|c|c|c|}
\hline & Agency & Rank & Mean & $\begin{array}{l}\text { Std. } \\
\text { Dev. }\end{array}$ & $\mathrm{N}$ & $\begin{array}{l}\% \text { Strongly } \\
\text { Agree/Agree }\end{array}$ \\
\hline $\begin{array}{l}\text { I would like climate or weather forecasts to inform the } \\
\text { services I provide }\end{array}$ & FSA & 2 & 3.21 & 0.83 & 3595 & $34 \%$ \\
\hline $\begin{array}{l}\text { I would like climate or weather forecasts to inform the } \\
\text { client decisions }\end{array}$ & NRCS & 1 & 3.70 & 0.84 & 1361 & $63 \%$ \\
\hline \multirow{2}{*}{$\begin{array}{l}\text { I believe there is an increased need for FSA/NRCS } \\
\text { programs in my service area due to changing weather } \\
\text { patterns }\end{array}$} & FSA & 1 & 3.31 & 0.98 & 3606 & $42 \%$ \\
\hline & NRCS & 3 & 3.34 & 1.10 & 1371 & $45 \%$ \\
\hline \multirow{2}{*}{$\begin{array}{l}\text { I am confident in my ability to apply weather forecast } \\
\text { and information to the services I provide }\end{array}$} & FSA & 3 & 3.04 & 0.81 & 3592 & $26 \%$ \\
\hline & NRCS & 2 & 3.38 & 0.90 & 1335 & $47 \%$ \\
\hline \multirow{2}{*}{$\begin{array}{l}\text { Extension staff, crop advisors, and formal or informal } \\
\text { advisors involved in agriculture often consult with me }\end{array}$} & FSA & 5 & 2.62 & 1.00 & 3597 & $19 \%$ \\
\hline & NRCS & 5 & 2.95 & 1.02 & 1297 & $30 \%$ \\
\hline \multirow{2}{*}{$\begin{array}{l}\text { In the past, inaccurate weather information has } \\
\text { negatively affected the quality of the services I provide }\end{array}$} & FSA & 4 & 2.57 & 0.80 & 3590 & $7 \%$ \\
\hline & NRCS & 6 & 2.76 & 0.80 & 1316 & $13 \%$ \\
\hline \multirow{2}{*}{$\begin{array}{l}\text { Weather forecasts and information are not available } \\
\text { when I need them for the services I provide }\end{array}$} & FSA & 6 & 2.56 & 0.78 & 3598 & $8 \%$ \\
\hline & NRCS & 7 & 2.50 & 0.83 & 1337 & $10 \%$ \\
\hline $\begin{array}{l}\text { In the past, accurate weather information has positively } \\
\text { affected the quality of the services that I provide }\end{array}$ & NRCS & 4 & 3.31 & 0.77 & 1329 & $38 \%$ \\
\hline
\end{tabular}


Table 4: Agreement with statements about climate change and natural resources; ranked on a five point Likert scale: (1) strongly disagree; (2) disagree; (3) neither agree nor disagree; (4) agree; (5) strongly agree. Questions adapted from Prokopy et al. 2013.

\begin{tabular}{|c|c|c|c|c|c|c|}
\hline & Agency & Rank & Mean & $\begin{array}{l}\text { Std. } \\
\text { Dev. }\end{array}$ & $\mathrm{N}$ & $\begin{array}{l}\text { \% Strongly } \\
\text { Agree/Agree }\end{array}$ \\
\hline \multirow{2}{*}{$\begin{array}{l}\text { It is important for producers to adapt to climate change } \\
\text { and ensure the long-term success of U.S. agriculture }\end{array}$} & FSA & 1 & 3.71 & 0.84 & 3569 & $65 \%$ \\
\hline & NRCS & 2 & 3.86 & 0.92 & 1322 & $72 \%$ \\
\hline \multirow{2}{*}{$\begin{array}{l}\text { Producers should take additional steps to protect their } \\
\text { operations from increased weather variability }\end{array}$} & FSA & 2 & 3.62 & 0.75 & 3564 & $61 \%$ \\
\hline & NRCS & 4 & 3.74 & 0.86 & 1372 & $68 \%$ \\
\hline $\begin{array}{l}\text { In my current role, I should help producers to prepare } \\
\text { for increased weather variability }\end{array}$ & FSA & 3 & 3.05 & 0.88 & 3567 & $29 \%$ \\
\hline $\begin{array}{l}\text { Assisting producers to prepare for increased weather } \\
\text { variability is a part of my job }\end{array}$ & NRCS & 5 & 3.44 & 0.95 & 1371 & $52 \%$ \\
\hline \multirow{2}{*}{$\begin{array}{l}\text { Producers should do more to reduce greenhouse gas } \\
\text { emissions from their farm operations }\end{array}$} & FSA & 4 & 3 & 0.95 & 3562 & $26 \%$ \\
\hline & NRCS & 6 & 3.38 & 1.06 & 1361 & $49 \%$ \\
\hline \multirow{2}{*}{$\begin{array}{l}\text { I have the knowledge and technical skill to help } \\
\text { producers deal with any weather-related threats to the } \\
\text { viability of their operation }\end{array}$} & FSA & 5 & 2.63 & 0.89 & 3572 & $14 \%$ \\
\hline & NRCS & 8 & 3.07 & 0.91 & 1373 & $34 \%$ \\
\hline \multirow{2}{*}{$\begin{array}{l}\text { Climate change is not a big issue because human } \\
\text { ingenuity will enable producers to adapt to changes }\end{array}$} & FSA & 6 & 2.61 & 0.9 & 3566 & $14 \%$ \\
\hline & NRCS & 11 & 2.4 & 0.98 & 1373 & $11 \%$ \\
\hline $\begin{array}{l}\text { It is important for producers to adapt to climate change } \\
\text { to ensure the long-term success of U.S. forestry }\end{array}$ & NRCS & 1 & 3.88 & 0.89 & 697 & $71 \%$ \\
\hline $\begin{array}{l}\text { It is important for producers to adapt to climate change } \\
\text { to ensure the long-term success of U.S. rangeland }\end{array}$ & NRCS & 3 & 3.79 & 0.97 & 814 & $69 \%$ \\
\hline $\begin{array}{l}\text { Producers should do more to reduce greenhouse gas } \\
\text { emissions from their forestry operations }\end{array}$ & NRCS & 7 & 3.25 & 1.04 & 701 & $39 \%$ \\
\hline $\begin{array}{l}\text { I am concerned that available best management } \\
\text { practice technologies are not effective enough to } \\
\text { protect the producers I advise from the impacts of } \\
\text { climate change }\end{array}$ & NRCS & 9 & 2.99 & 0.96 & 1369 & $30 \%$ \\
\hline $\begin{array}{l}\text { There's too much uncertainty about the impacts of } \\
\text { climate change to justify advising or discussing with } \\
\text { producers any changes to their management practices } \\
\text { and strategies }\end{array}$ & NRCS & 10 & 2.94 & 1.08 & 1375 & $32 \%$ \\
\hline
\end{tabular}




\section{Climate and weather concerns}

Respondents were asked to rank a list of climate concerns on a four-point Likert scale: (1) not concerned; (2) slightly concerned; (3) concerned; (4) very concerned. Results are aggregated nationally (Figures 6-10), and presented in terms of the most common climate concern per state (Figures 11 and 12). For both FSA and NRCS, the most common climate concern in terms of number of states that ranked it highest and the nationally aggregated mean was longer dry periods and droughts. For FSA, this concern covered the vast majority of states, but for NRCS there was a greater diversity of concerns, which likely has to do with the different mission areas of these two agencies. The second most common concern for both agencies was more frequent extreme rains, followed by increased flooding. Other results show geographic patterns, such as concern over higher incidence of wildfire in the northwest, and concern over increased soil erosion in the Upper Midwest and Great Lakes region. 


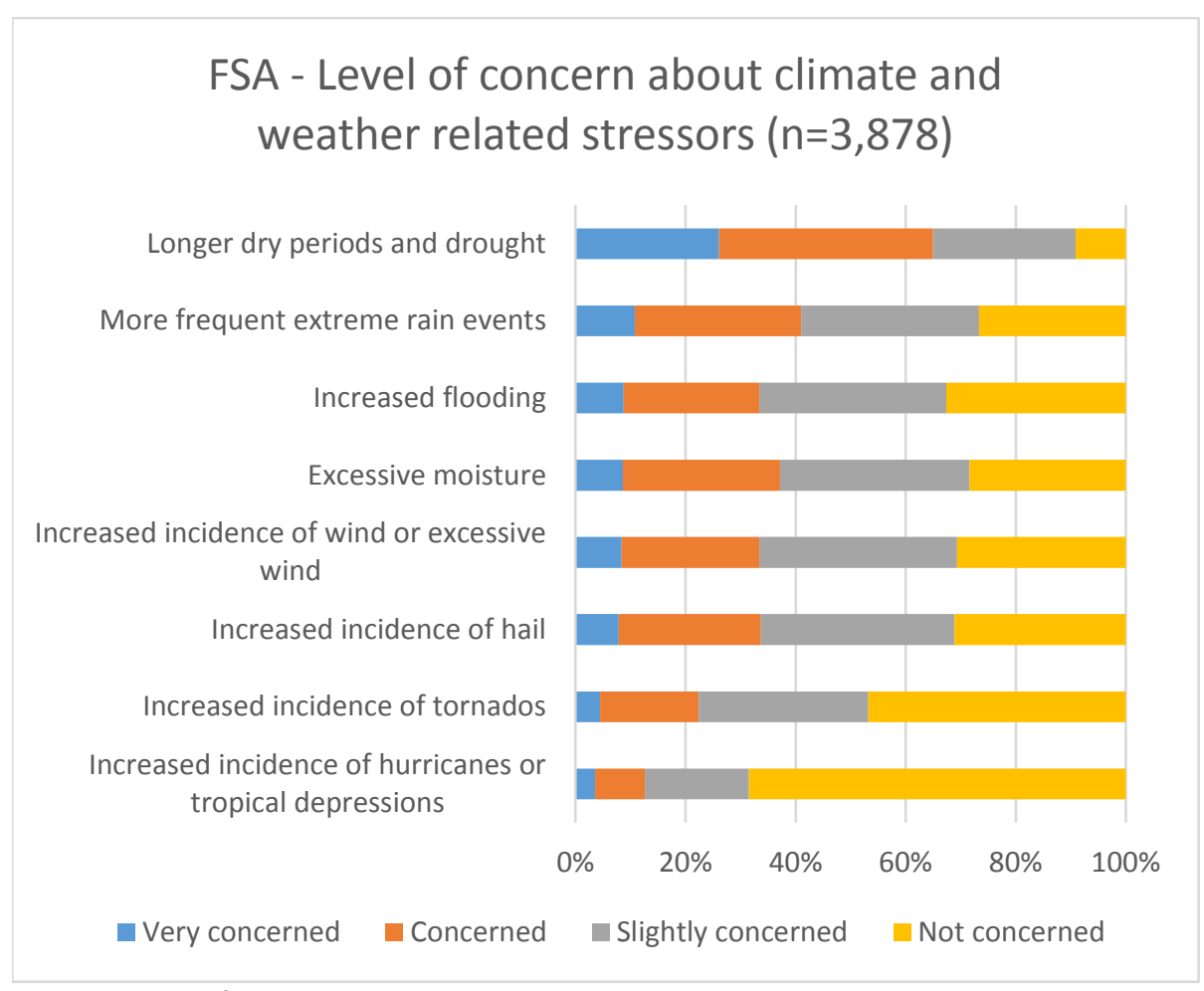

Figure 6: Level of concern about climate and weather stressors among FSA respondents. Questions adapted from Prokopy et al. 2013.

\section{NRCS - Level of concern about climate and weather related stressors $(n=1,382)$}

Longer dry periods and drought

More frequent extreme rains

Increased flooding

Increased incidences of wind storms

Excessive moisture

Increased incidence of tornado events

Increased incidence of hail events

Increased incidences of

hurricanes/tropical depressions

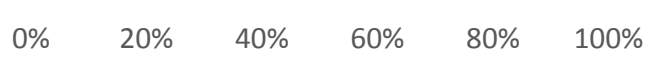

- Very concerned $\quad$ Concerned Slightly concerned $\quad$ Not concerned

Figure 7: Level of concern about climate and weather stressors among NRCS respondents. Questions adapted from Prokopy et al. 2013. 


\section{FSA - Level of concern about agricultural stressors $(n=3,864)$}

Increased heat stress on crops

Increased heat stress on livestock

Increased weed pressure

Increased insect pressure

Increased soil erosion

Higher incidence of crop disease

Increased loss of nutrients into waterways

Increases in saturated soils and ponded water

Increased incidence of crop stress or loss due to frost or freeze

Increased amounts of animal manure into waterways

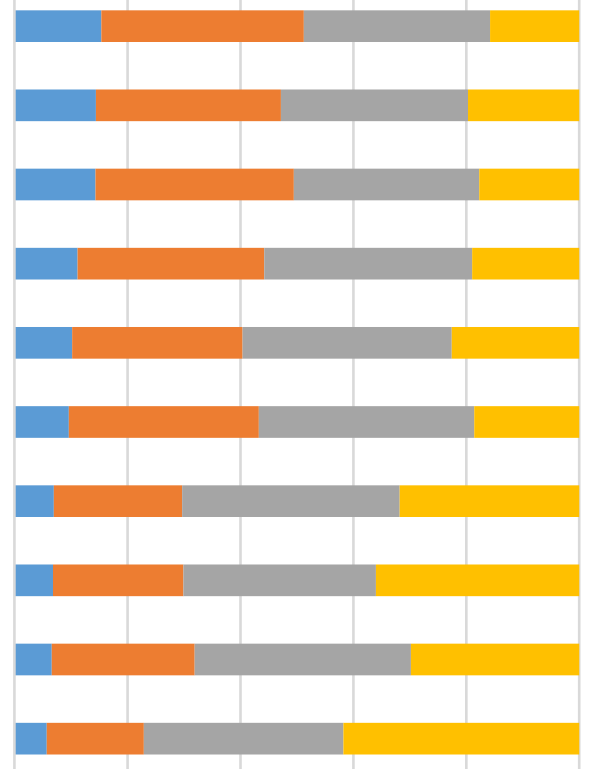

$\begin{array}{llllll}0 \% & 20 \% & 40 \% & 60 \% & 80 \% & 100 \%\end{array}$

Very concerned Concerned

- Slightly concerned Not concerned
NRCS - Level of concern about agricultural stressors $(n=1,378)$

Increased soil erosion

Increased weed pressure

Increased heat stress on crops

Increased pressure from insect species

Increased loss of nutrients into waterways

Increased loss of animal manure into waterways

Increased heat stress on livestock

Increases in saturated soils and ponded water

Higher incidence of crop/plant disease

Increased incidence of crop stress or loss due to frost or freeze
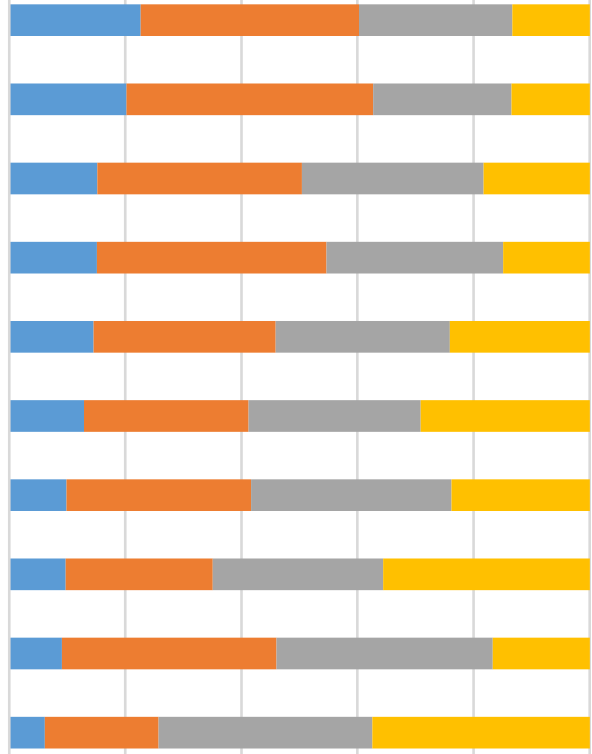

$\begin{array}{llllll}0 \% & 20 \% & 40 \% & 60 \% & 80 \% & 100 \%\end{array}$

Very concerned $\quad$ Concerned $\quad$ Slightly concerned $\quad$ Not concerned

Figure 9: Level of concern about agricultural stressors among NRCS respondents. Questions adapted from Prokopy et al. 2013.

Figure 8: Level of concern about agricultural stressors among FSA respondents. Question adapted from Prokopy et al. 2013.

NRCS - Level of concern about forestry stressors $\left(n=704^{*}\right)$

Higher incidence of tree pathogens

Higher incidence of wildfire

Increased heat stress on timber stands

Increased tree loss due to high/extreme wind events

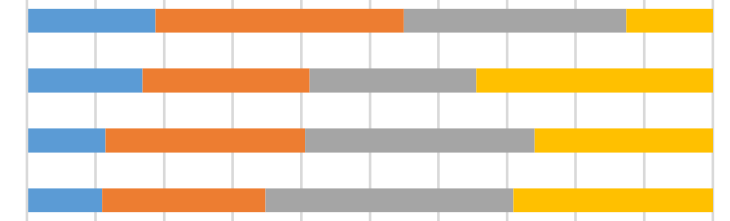

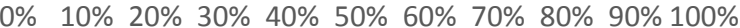

Very concerned $\square$ Concerned $\quad$ Slightly concerned $\quad$ Not concerned

Figure 10: Level of concern about forestry stressors among NRCS respondents

* Only those who responded that they work with forest land owners were given these statements, with the exception

of "higher incidence of wildfire." For that statement, $n=1,380$ ) 


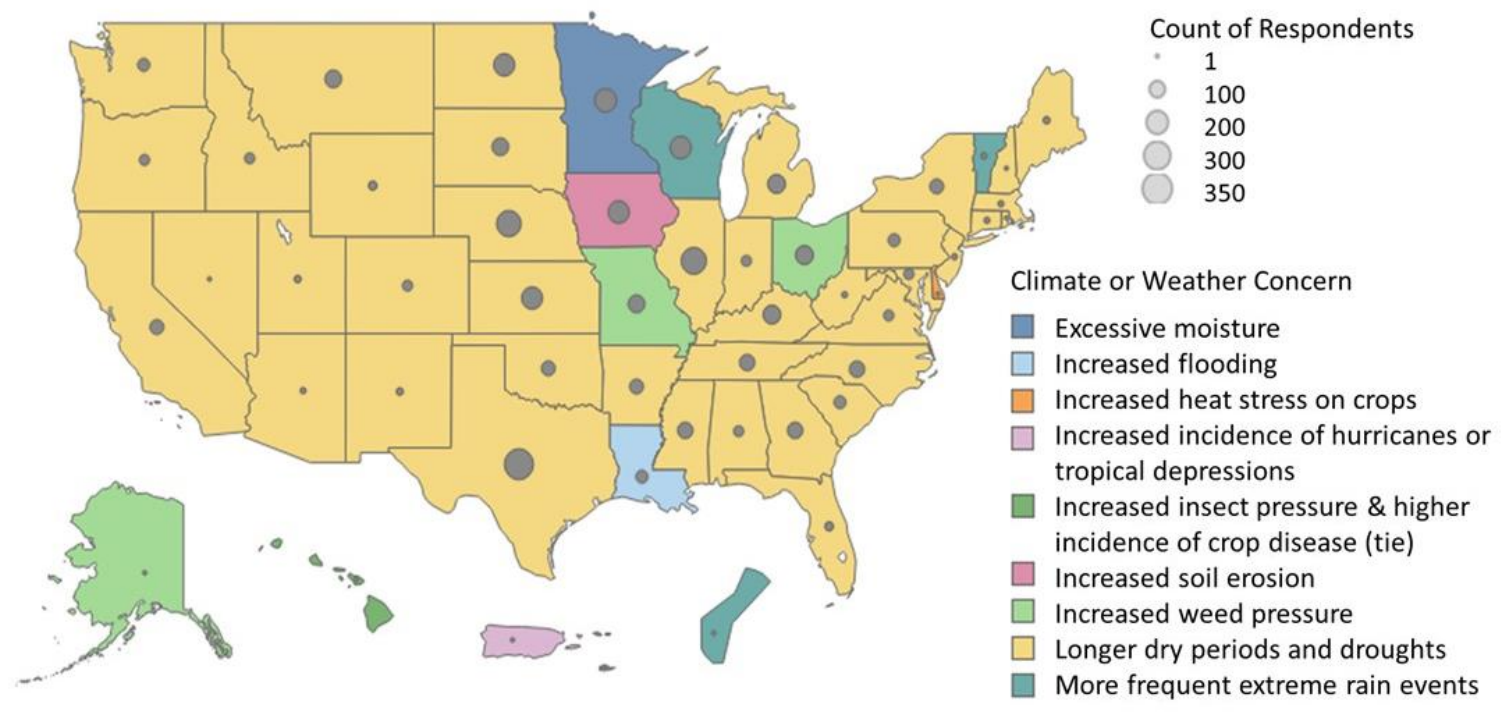

Figure 11: Most common climate or weather concern of FSA respondents by state $(n=3,571)$

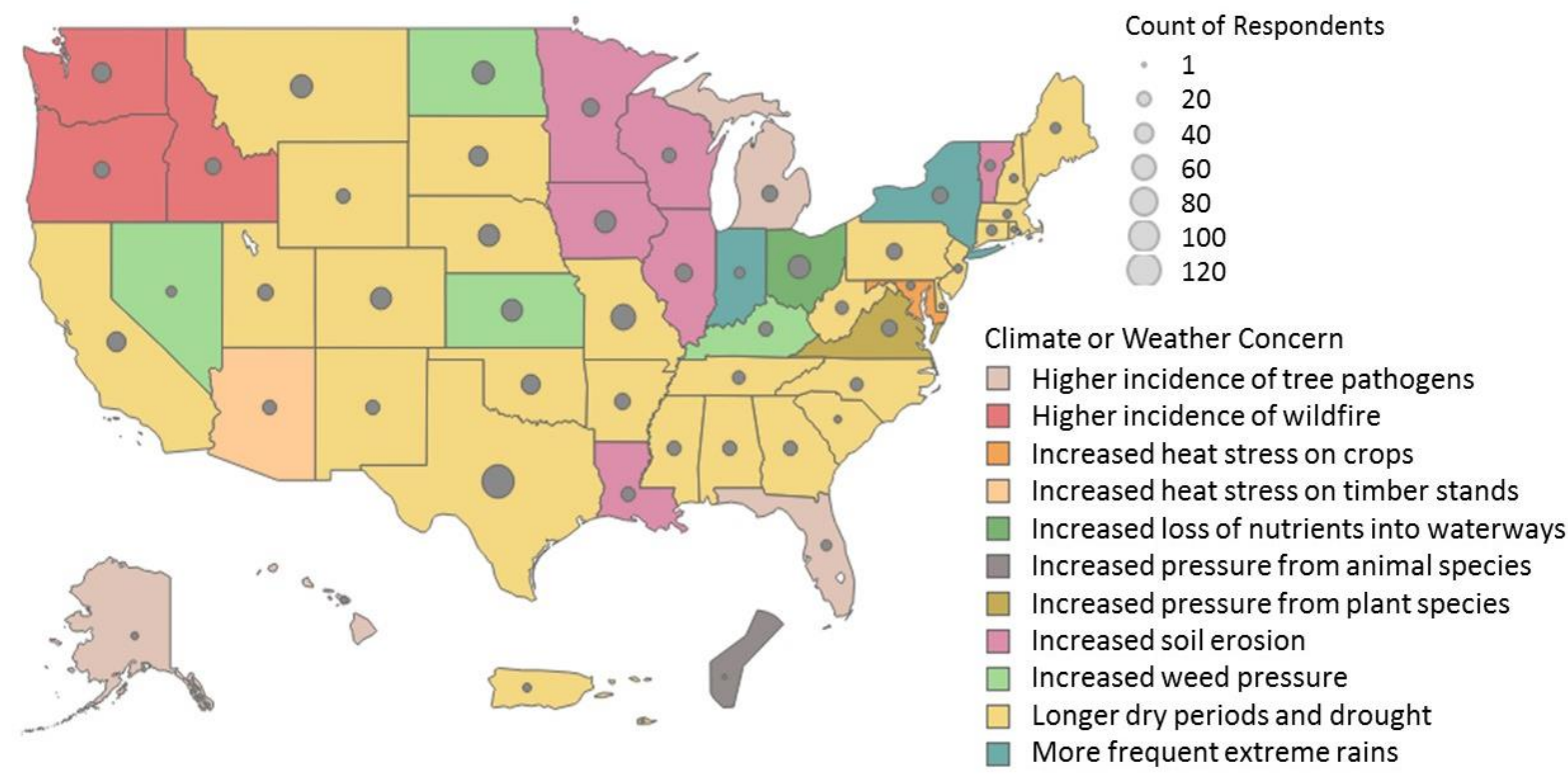

Figure 12: Most common climate or weather concern of NRCS respondents by state $(n=1,376)$ 


\section{Conclusion}

The mission of the Climate Hubs is to work with USDA agencies and partners to develop and deliver science-based, region-specific information and technologies to agricultural and natural resource managers, enabling climate-informed decision-making, and assisting in the implementation of those decisions. The missions of NRCS and FSA include supporting conservation management of agricultural, range, and forested lands in the United States. The USDA Climate Hubs, NRCS, and FSA work together to support land managers as they adapt to more variable and extreme weather associated with climate change.

Multiple opportunities were identified in this survey, including a disparity between the amount of field staff who want to use weather and climate resources during service provision and those who are confident in their ability to do so. A significant proportion expressed interest in their role in assisting land managers in adapting to climate change, but support is needed to determine the appropriate avenues. Additionally, there are several tools and resources about which staff are unfamiliar or not using. As a result of this survey analysis, we identified four areas of potential collaboration between FSA, NRCS, and the Climate Hubs:

1. Provide training and support for FSA and NRCS employees to work with and understand weather and climate data, tools, and resources, with a focus on those climate and weather stressors of greatest concern.

2. Better integrate specific weather and climate tools into specific FSA and NRCS program areas and existing tools used by these agencies.

3. Hone outreach and education on climate- and weather-related issues by linking them to existing programs that help producers reduce climate-related risks on farm (such as the Conservation Reserve Enhancement Program).

4. Develop outreach and education messaging through the USDA Public Affairs Division on climate and weather-related issues. Messaging could be linked to existing agency efforts, such as the NRCS Soil Health Initiative, directly tied to conservation practices, and aligned with conservation compliance expectations that reduce risks, increase productivity, and build resilience across sectors.

U.S. agriculture and natural resources sectors will need to adapt to a changing climate to ensure the resilience of diverse agricultural, rangeland, and forestry sectors. The Climate Hubs, in partnership with FSA and NRCS, under the broader mission of OneUSDA, are well-staged to support USDA agencies in providing the best available science, tools, and communication resources to address climate impacts and support agency employees to assist land managers in reducing climate risks now, and in the future. 


\section{References}

Dillman, D. A., Smyth, J. D. and Christian, L. M. (2008) Internet, mail, and mixed-mode surveys: The tailored design method. 2nd edition, Internet Mail and MixedMode Surveys The tailored design method. 2nd editio. Hoboken, NJ: John Wiley \& Sons, Ltd. doi: $10.2307 / 41061275$.

Lal, R., Delgado, J. A., Groffman, P. M., Millar, N., Dell, C., \& Rotz, A. (2011). Management to mitigate and adapt to climate change. Journal of Soil and Water Conservation, 66(4), 276-285.

Masters, J. (2008) Winter forecast part III: The Old Farmers Almanac, Weather Underground. Available at:

http://web.archive.org/web/20151120132843/http:/www.wunderground.com/blog/JeffMasters/co mment.html?entrynum=1161 (Accessed: 15 May 2017).

Prokopy, L. S., Haigh, T., Mase, A. S., Angel, J., Hart, C., Knutson, C., Lemos, M. C., Lo, Y.-J., McGuire, J., Morton, L. W., Perron, J., Todey, D. and Widhalm, M. (2013) ‘Agricultural advisors: a receptive audience for weather and climate information?', Weather, Climate, and Society, 5(2), pp. 162-167. doi: 10.1175/WCAS-D-12-00036.1.

Samenow, J. (2016) 'Meteorologists smartly rip Old Farmer's Almanac forecast for cold winter in the East', The Washington Post, 16 August. Available at: https://www.washingtonpost.com/news/capital-weather-gang/wp/2015/08/17/meteorologists$\underline{\text { smartly-rip-old-farmers-almanac-forecast-for-cold-winter-in-the- }}$ $\underline{\text { east/?tid=a_inl\&utm_term }=.60967061 \mathrm{c} 6 \mathrm{ea}}$. 


\section{Appendices:}

Appendix A: Respondent demographic and occupational figures

\section{FSA Response Rate by State}

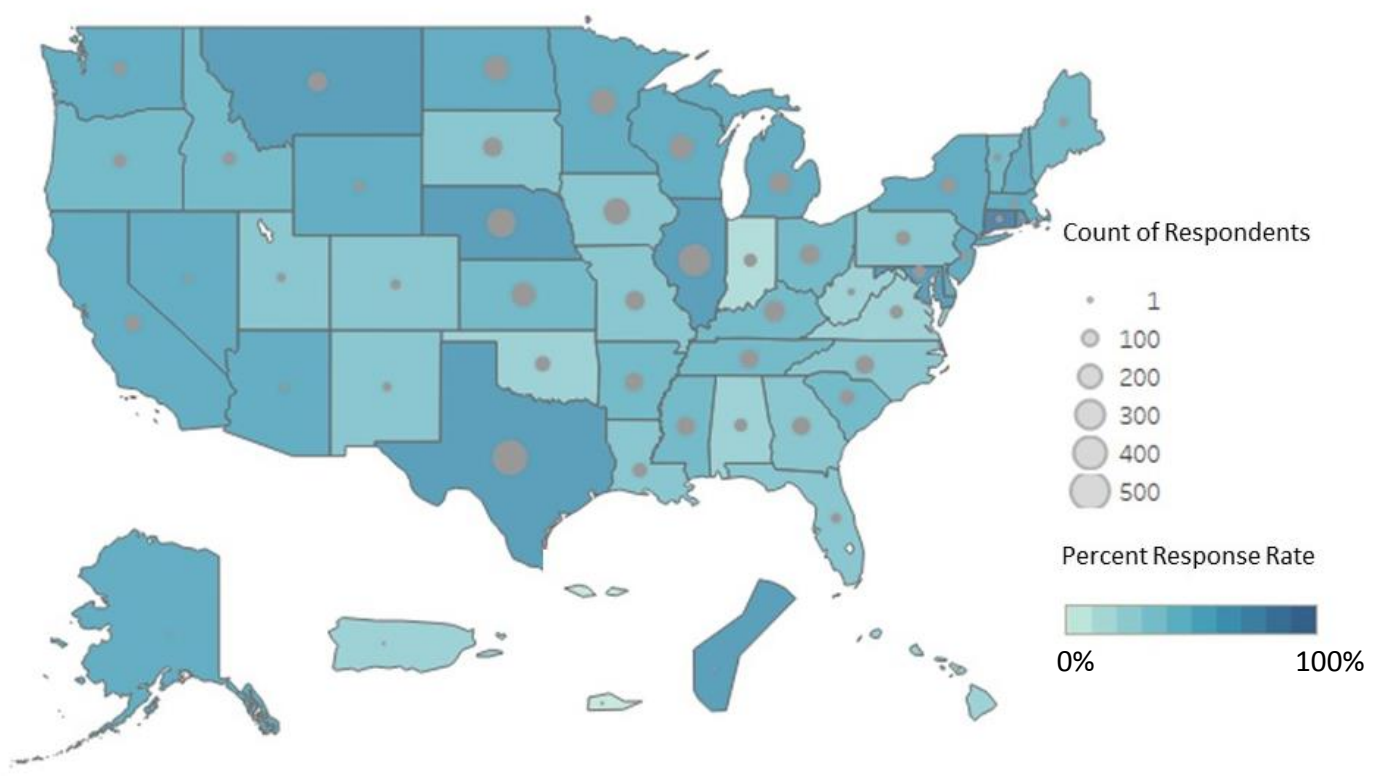

Figure A1: Count of FSA respondents to climate and weather survey by state $(n=4,238)$

\section{NRCS Response Rate by State}

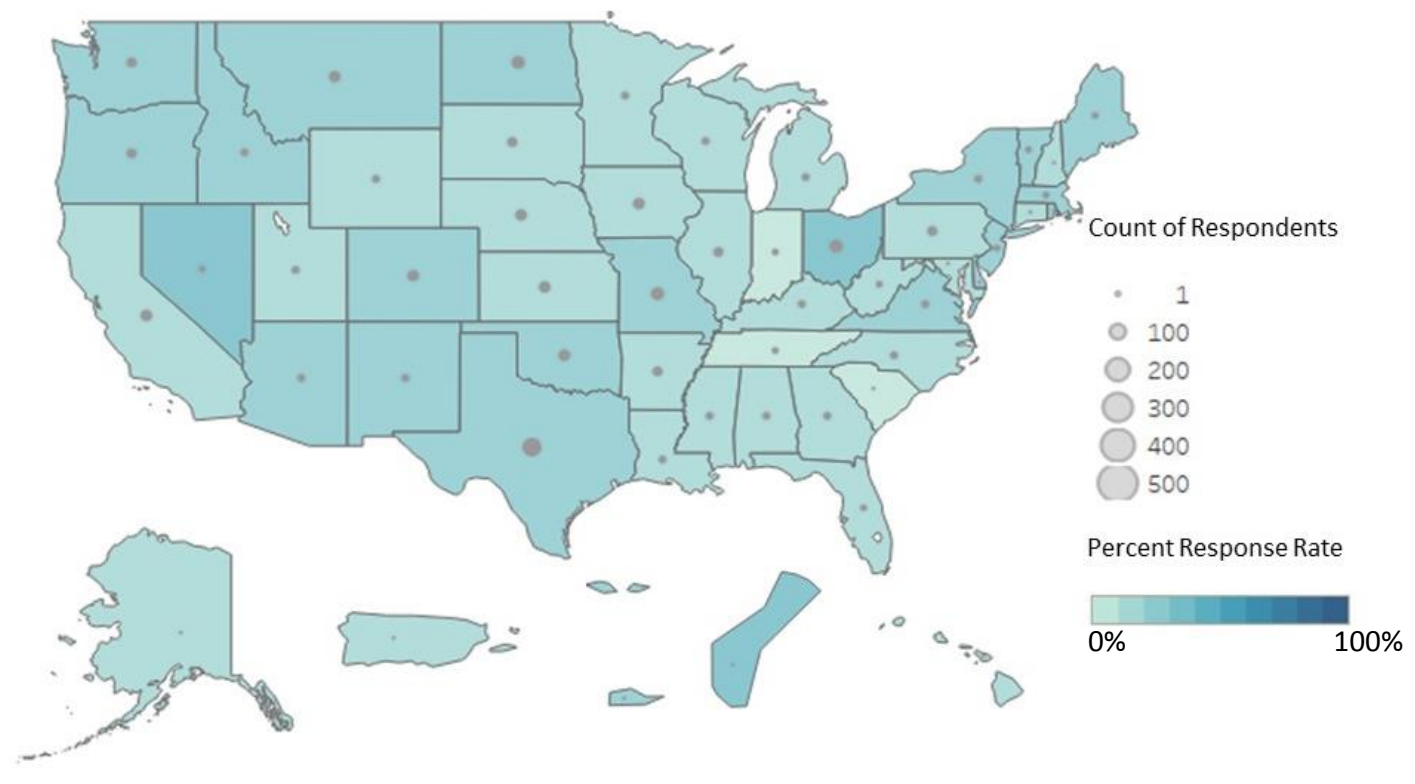

Figure A2: Count of NRCS respondents to climate and weather survey by state $(n=1,893)$ 
Table A1: Response to the question, "In your current job, do you work directly with producers on a regular basis?"

\begin{tabular}{|l|r|r|r|r|}
\hline & FSA Count & FSA \% & NRCS Count & NRCS \% \\
\hline Yes & 4,238 & $92 \%$ & 1,597 & $86 \%$ \\
\hline No & 383 & $8 \%$ & 260 & $14 \%$ \\
\hline
\end{tabular}

Table A2: Location/work jurisdiction of respondents

\begin{tabular}{|l|l|l|}
\hline & FSA $(\mathrm{n}=3,601)$ & NRCS $(\mathrm{n}=1,365)$ \\
\hline County Office & $95 \%$ & $74 \%$ \\
\hline Area Office & NA & $12 \%$ \\
\hline State Office & $3 \%$ & $10 \%$ \\
\hline $\begin{array}{l}\text { Regional Office/Technology } \\
\text { Support Center }\end{array}$ & NA & $1 \%$ \\
\hline Other & $1 \%$ & $3 \%$ \\
\hline
\end{tabular}

${ }^{1}$ Individuals associated with Regional Offices or Technology Support Centers were intentionally excluded from the sample, as their position titles do not suggest working directly with land managers

Table A3: Position titles of FSA and NRCS respondents (only top 5 reported)

\begin{tabular}{|l|r|l|r|}
\hline \multicolumn{2}{|l|}{ FSA $(\mathrm{n}=3,469)$} & NRCS $(\mathrm{n}=1,364)$ & $24.5 \%$ \\
\hline Program technician & $56.1 \%$ & District Conservationists & $18.6 \%$ \\
\hline County executive director & $22.1 \%$ & Soil Conservationist & $15.8 \%$ \\
\hline Farm loan officer & $4.5 \%$ & Soil Conservation/Engineering Technician & $7.8 \%$ \\
\hline Key or lead program technician & $4.0 \%$ & Engineer & $7.8 \%$ \\
\hline Farm loan manager & $3.9 \%$ & Resource Conservationist & \\
\hline
\end{tabular}

Table A4: NRCS responses to, "Please indicate whether you work with the following land managers in your daily activities (select all that apply)."

\begin{tabular}{|l|r|r|}
\hline & Percent & Count (multiple answers allowed) \\
\hline Farmers & $83 \%$ & 1568 \\
\hline Forest Landowners & $44 \%$ & 831 \\
\hline Ranchers & $51 \%$ & 960 \\
\hline $\begin{array}{l}\text { I do not work with land managers in my daily } \\
\text { activities }\end{array}$ & $14 \%$ & 260 \\
\hline
\end{tabular}




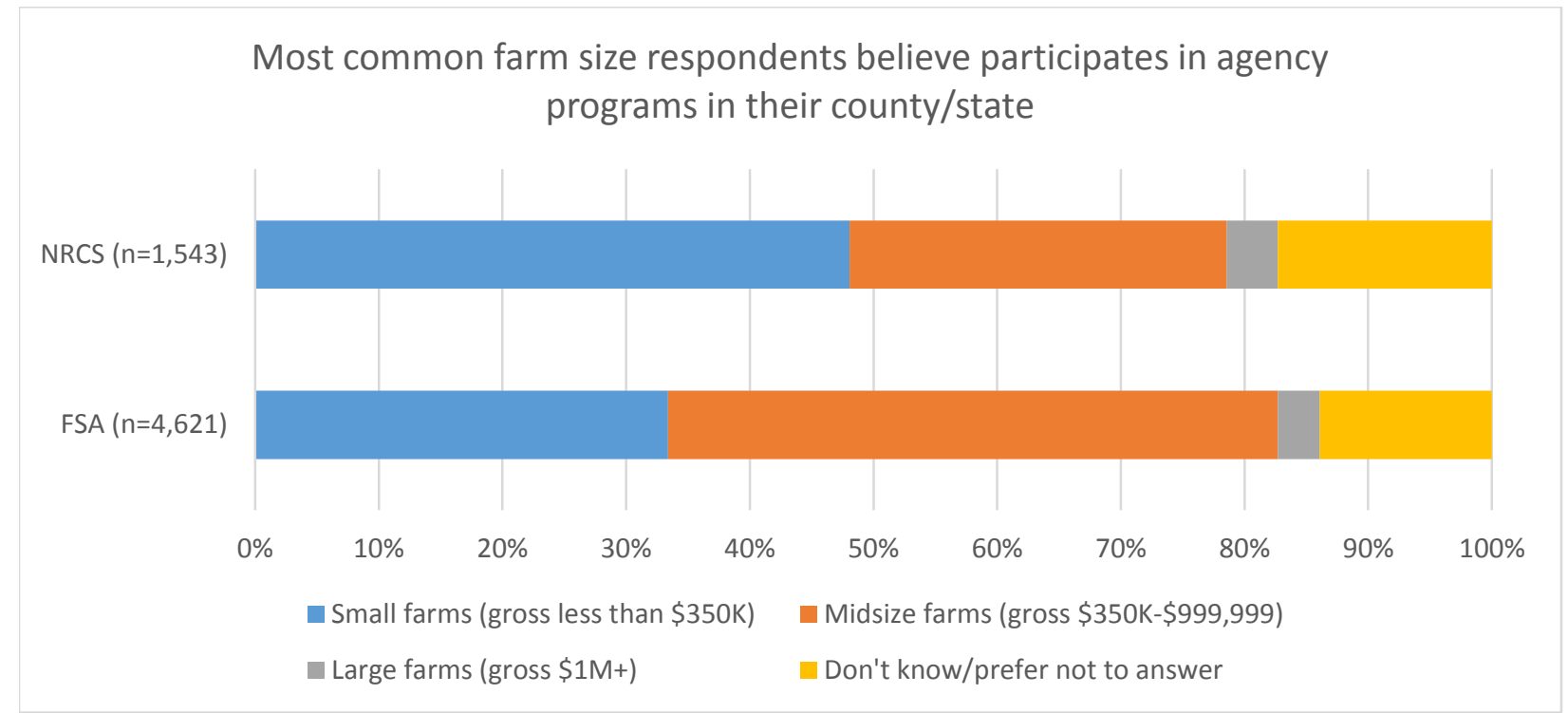

Figure A3: Most common farm size in gross revenue that respondents from FSA and NRCS report working with in dollars.

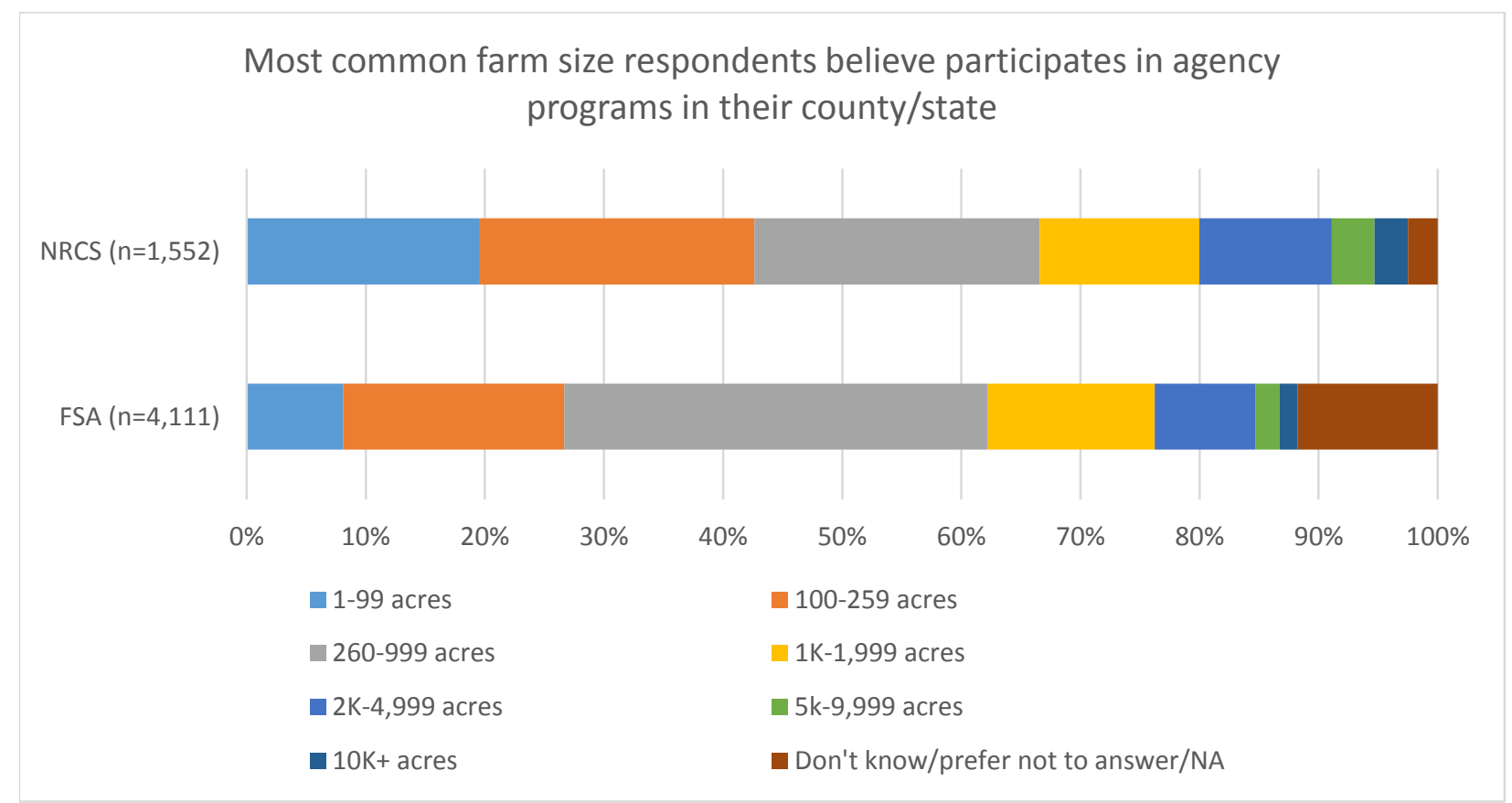

Figure A4: Most common operation size in total acres that respondents believe characterize farmers who use participate in agency programs in their county/state. 
Table A5: Responses to "What do your customers typically grow/produce?" (check all that apply)

\begin{tabular}{|l|r|r|}
\hline & FSA $(\mathrm{n}=4,120)$ & NRCS $(\mathrm{n}=1,556)$ \\
\hline Alfalfa and other hay & $71.3 \%$ & $70.44 \%$ \\
\hline Aquaculture & $5.0 \%$ & $3.79 \%$ \\
\hline Cattle and calves & $80.3 \%$ & $82.65 \%$ \\
\hline Dairy/milk from cows & $40.8 \%$ & $32.46 \%$ \\
\hline Forest/timber products & Not Asked & $37.40 \%$ \\
\hline $\begin{array}{l}\text { Fruits, tree nuts, and } \\
\text { berries }\end{array}$ & $18.8 \%$ & $18.12 \%$ \\
\hline $\begin{array}{l}\text { Grains, oilseeds, dry } \\
\text { beans, and dry peas }\end{array}$ & $85.8 \%$ & $64.07 \%$ \\
\hline Hogs and pigs & $30.2 \%$ & $17.87 \%$ \\
\hline $\begin{array}{l}\text { Non-timber forest } \\
\text { products }\end{array}$ & Not Asked & $5.40 \%$ \\
\hline $\begin{array}{l}\text { Nursery, greenhouse, } \\
\text { floriculture, sod... }\end{array}$ & $13.8 \%$ & $11.89 \%$ \\
\hline $\begin{array}{l}\text { Other livestock and } \\
\text { livestock products }\end{array}$ & $23.5 \%$ & $24.49 \%$ \\
\hline Other row crops & $26.2 \%$ & $20.24 \%$ \\
\hline Poultry and eggs & $18.7 \%$ & $19.99 \%$ \\
\hline $\begin{array}{l}\text { Vegetables, melons, } \\
\text { potatoes, and sweet } \\
\text { potatoes }\end{array}$ & $33.6 \%$ & $31.75 \%$ \\
\hline Other (write in) & $4.70 \%$ & $4.50 \%$ \\
\hline
\end{tabular}

Table A6: Respondents who own, operate, or have a financial state in a farm or forest land

\begin{tabular}{|l|l|l|l|}
\hline & $\begin{array}{l}\text { FSA Farm Ownership/ } \\
\text { Stake (n=4,118) }\end{array}$ & $\begin{array}{l}\text { NRCS Farm Ownership/ } \\
\text { Stake (n=1,559) }\end{array}$ & $\begin{array}{l}\text { NRCS Forest } \\
\text { Ownership/ Stake } \\
(\mathrm{n}=1,559)\end{array}$ \\
\hline Yes & $43 \%$ & $33 \%$ & $15 \%$ \\
\hline No & $52 \%$ & $61 \%$ & $81 \%$ \\
\hline Prefer not to answer & $5 \%$ & $6 \%$ & $4 \%$ \\
\hline
\end{tabular}

Table A7: Size of farming or forestry operations in which respondents have a financial interest

\begin{tabular}{|l|l|r|}
\hline Farm Ownership/Stake & FSA (n=1,621) & NRCS (n=516) \\
\hline Large farms (gross sales \$1,000,000 or more) & $3 \%$ & $1 \%$ \\
\hline $\begin{array}{l}\text { Midsize farms (gross sales between \$350,000- } \\
\$ 999,999)\end{array}$ & $16 \%$ & $8 \%$ \\
\hline Small farms (gross sales less than \$350,000) & $75 \%$ & $\mathbf{8 3 \%}$ \\
\hline Prefer not to answer & $7 \%$ & NRCS (n=216) \\
\hline Forest Ownership/Stake & $>1 \%$ \\
\hline Industrial forest landowner (average harvest over 2 million board feet/year) & $87 \%$ \\
\hline Small forest landowner (average harvest under 2 million board feet/year) & $13 \%$ \\
\hline Prefer not to answer & & 9 \\
\hline
\end{tabular}


Table A8: Race of respondents compared to agency population

\begin{tabular}{|c|c|c|c|c|}
\hline & $\begin{array}{l}\text { FSA Agency } \\
(n=12,593)\end{array}$ & $\begin{array}{l}\text { FSA Survey } \\
(n=3,840)\end{array}$ & NRCS Agency & $\begin{array}{l}\text { NRCS Survey } \\
(n=1,361)\end{array}$ \\
\hline $\begin{array}{l}\text { American Indian/ Alaska } \\
\text { Native }\end{array}$ & $1 \%$ & $2 \%$ & $2 \%$ & $3 \%$ \\
\hline Asian & $1 \%$ & $0 \%$ & $1 \%$ & $0 \%$ \\
\hline $\begin{array}{l}\text { Black or African } \\
\text { American }\end{array}$ & $5 \%$ & $2 \%$ & $9 \%$ & $2 \%$ \\
\hline $\begin{array}{l}\text { Native Hawaiian or other } \\
\text { Pacific Islander }\end{array}$ & $<1 \%$ & $0 \%$ & $<1 \%$ & $1 \%$ \\
\hline More than one/other* & $1 \%$ & NA & $2 \%$ & $2 \%$ \\
\hline White & $90 \%$ & $86 \%$ & $86 \%$ & $75 \%$ \\
\hline Prefer not to Answer & NA & $10 \%$ & NA & $17 \%$ \\
\hline
\end{tabular}

Table A9: Ethnicity of respondents

\begin{tabular}{|l|r|r|}
\hline Ethnicity & FSA $(\mathrm{n}=3,534)$ & NRCS $(\mathrm{n}=1,329)$ \\
\hline Hispanic or Latino & $3 \%$ & $5 \%$ \\
\hline Not-Hispanic or Latino & $87 \%$ & $75 \%$ \\
\hline $\begin{array}{l}\text { Other/Prefer not to } \\
\text { answer }\end{array}$ & $10 \%$ & $24 \%$ \\
\hline
\end{tabular}

Table A10: Sex of respondents compared to agency population

\begin{tabular}{|l|l|r|r|l|}
\hline & FSA Agency & $\begin{array}{l}\text { FSA Survey } \\
(\mathrm{n}=3,548)\end{array}$ & NRCS Agency & $\begin{array}{l}\text { NRCS Survey } \\
(\mathrm{n}=1,362)\end{array}$ \\
\hline Male & $32 \%$ & $26 \%$ & $63 \%$ & $63 \%$ \\
\hline Female & $68 \%$ & $67 \%$ & $37 \%$ & $24 \%$ \\
\hline Prefer not to answer & NA & $7 \%$ & NA & $12 \%$ \\
\hline
\end{tabular}

Table A11: Age breakdown of respondents

\begin{tabular}{|c|c|c|c|c|}
\hline Age & FSA Agency & $\begin{array}{l}\text { FSA Respondents } \\
(\mathrm{n}=3,078)\end{array}$ & NRCS Agency & $\begin{array}{l}\text { NRCS Respondents } \\
(\mathrm{n}=1,271)\end{array}$ \\
\hline $20-29$ & $6 \%$ & $12 \%$ & $9 \%$ & $8 \%$ \\
\hline $30-39$ & $16 \%$ & $17 \%$ & $26 \%$ & $22 \%$ \\
\hline $40-49$ & $19 \%$ & $17 \%$ & $22 \%$ & $21 \%$ \\
\hline $50-59$ & $40 \%$ & $41 \%$ & $32 \%$ & $31 \%$ \\
\hline $60-69$ & $19 \%$ & $13 \%$ & $10 \%$ & $17 \%$ \\
\hline
\end{tabular}

Table A12: Highest level of education of respondents

\begin{tabular}{|l|r|r|}
\hline & FSA $(\mathrm{n}=3,916)$ & NRCS $(\mathrm{n}=1,394)$ \\
\hline Some formal edu, less than high-school & $0 \%$ & $0 \%$ \\
\hline High-school graduate/GED & $10 \%$ & $2 \%$ \\
\hline Some college & $19 \%$ & $4 \%$ \\
\hline 2-year college or tech degree & $15 \%$ & $5 \%$ \\
\hline 4-year college & $46 \%$ & $65 \%$ \\
\hline Graduate degree & $8 \%$ & $24 \%$ \\
\hline Prefer not to answer & $4 \%$ & \\
\hline
\end{tabular}


NRCS - In what general subject area is your degree? $(n=1,283)$

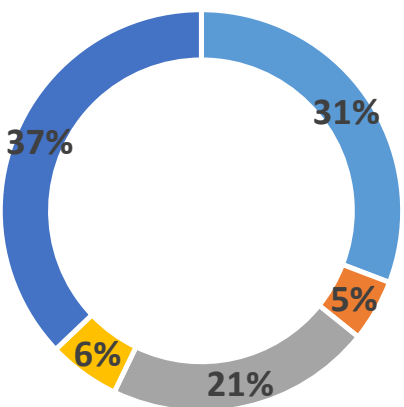

natural Resource Management $\square$ Forestry $\square$ Agronomy $\square$ Animal Science - Other

Figure A5: General subject area of degree for NRCS respondents 


\section{FSA Survey}

Intro Thank you for taking time to answer the following questions about your role as an agricultural service provider and your thoughts about weather-related risk. Your answers will be used to improve USDA program administration, as well as contribute to important research on U.S. agriculture and adapting to a changing climate. The survey should take you approximately 20 minutes to complete.

Indicates that the question, sub-question, or answer choice is visible to respondents who report working with any land managers in their daily activities (Farmer by lain Hector from Noun Project)

Questions and sub-questions without an icon are visible to all respondents

* Indicates a question taken or adapted from Prokopy et al. 2013

In your current job, do you work directly with producers on a regular basis?

Yes

No 
费

Which of the following farm size (in sales) do you estimate has the highest participation rate in FSA programs in your state (if you work for a State Office) or County (if you work for a County Office)?

Small farms (gross sales less than $\$ 350,000$ )

Midsize farms (gross sales between $\$ 350,000-\$ 999,999$ )

Large farms (gross sales $\$ 1,000,000$ or more)

Don't know or prefer not to answer

通 作 programs in your state (if you work for a State Office) or County (if you work for a County Office)?

$1-99$ acres

$100-259$ acres

260-999 acres

$1,000-1,999$ acres

2,000-4,999 acres

$5,000-9,999$ acres

10,000 acres or more

Don't know or prefer not to answer 
Dairy/milk from cows

Alfalfa and other hay

Cattle and calves

Grains, oilseeds, dry beans, and dry peas

Other row crops (e.g. tobacco, cotton and cottonseed)

Nursery, greenhouse, floriculture, sod, cut Christmas trees and other short-rotation woody crops, and other specialty crops

Vegetables, melons, potatoes, and sweet potatoes

Fruit, tree nuts, and berries

Poultry and eggs

Other livestock and livestock products: horses, ponies, mules, burros, and donkeys, sheep, goats, wool, mohair, and milk other than cow

Aquaculture

Hogs and pigs

Other 
In addition to working for FSA, do you operate, own, or have a financial interest in a farm or farms?

Yes

No

Prefer not to answer

If response to previous question is yes: Please indicate the average size of the farm or farms in which you have financial interest(s) (select one).

Small farm (gross sales less than $\$ 350,000$ )

Midsize farm (gross sales between $\$ 350,000-\$ 999,999)$

Large farm (gross sales $\$ 1,000,000$ or more)

Prefer not to answer

Are you currently a member of an FSA County or State Committee?

Yes

No

Prefer not to answer 


\begin{tabular}{|c|c|c|c|c|}
\hline $\begin{array}{l}\text { Do you consider historical weather trends and/or forecasts } \\
\text { when you discuss the following topic areas with producers, } \\
\text { either formally or informally?* }\end{array}$ & $\begin{array}{c}\text { Yes, I } \\
\text { do }\end{array}$ & $\begin{array}{l}\text { No, but I } \\
\text { would if I had } \\
\text { better } \\
\text { information }\end{array}$ & $\begin{array}{l}\text { No, I } \\
\text { don't }\end{array}$ & $\begin{array}{l}\text { I don't } \\
\text { discuss } \\
\text { these topics } \\
\text { with } \\
\text { producers }\end{array}$ \\
\hline \multicolumn{5}{|l|}{ Crop rotations and field assignments } \\
\hline \multicolumn{5}{|l|}{ Crop and/or variety choices } \\
\hline \multicolumn{5}{|l|}{ Livestock purchases } \\
\hline \multicolumn{5}{|l|}{ Livestock genetics } \\
\hline \multicolumn{5}{|l|}{ Fertilizer purchase and application } \\
\hline \multicolumn{5}{|l|}{ Pesticide purchases and application } \\
\hline \multicolumn{5}{|l|}{ Fuel purchases } \\
\hline \multicolumn{5}{|l|}{ Purchasing crop insurance or NAP coverage } \\
\hline \multicolumn{5}{|l|}{ Tillage decisions } \\
\hline \multicolumn{5}{|l|}{ Integrated pest management practices } \\
\hline \multicolumn{5}{|l|}{ Planting or harvest schedule } \\
\hline \multicolumn{5}{|l|}{ Irrigation systems } \\
\hline \multicolumn{5}{|l|}{ Agricultural drainage systems } \\
\hline Market information (e.g., commodity prices, futures forecasts) & & & & \\
\hline
\end{tabular}




\section{Crop and commodity storage \\ Crop yields (individual or county)}

In general, how dependent are you on the following types of weather information to do your job?*

\begin{tabular}{l|ccc} 
Historical weather trends & Not dependent & $\begin{array}{c}\text { Slightly } \\
\text { dependent }\end{array}$ & $\begin{array}{c}\text { Moderately } \\
\text { dependent }\end{array}$ \\
Weather data for the past 12 \\
months
\end{tabular}


Do you use any of the following weather-related resources? Note that these resources may be accessible via newsletters, websites, meetings, radio, and other sources and they may not have the exact same name listed here.*

Crop disease forecasts
Insect forecasts
Evapotranspiration (ET)
index
Growing degree day tools
Forage dry down index
U.S. Drought Monitor or
Outlook
Farmers' Almanac
Livestock heat index
temperature
watellite data/indices of
status, precipitation or
tor




\begin{tabular}{|c|c|c|c|c|c|}
\hline $\begin{array}{l}\text { Please indicate your level of } \\
\text { agreement with each of the } \\
\text { following statements. }{ }^{*}\end{array}$ & $\begin{array}{l}\text { Strongly } \\
\text { disagree }\end{array}$ & Disagree & $\begin{array}{l}\text { Neither } \\
\text { agree nor } \\
\text { disagree }\end{array}$ & Agree & $\begin{array}{c}\text { Strongly } \\
\text { agree }\end{array}$ \\
\hline $\begin{array}{c}\text { In the past } 5 \text { years, I have noticed } \\
\text { more variable/unusual weather in } \\
\text { my area }\end{array}$ & & & & & \\
\hline $\begin{array}{l}\text { To cope with increasing climate } \\
\text { variability, changing farming } \\
\text { practices is important for the long- } \\
\text { term success of the producers in my } \\
\text { service area }\end{array}$ & & & & & \\
\hline $\begin{array}{c}\text { Changes in weather patterns are } \\
\text { hurting the producers in my service } \\
\text { area }\end{array}$ & & & & & \\
\hline $\begin{array}{l}\text { Producers in my service area have } \\
\text { suffered due to inaccurate weather } \\
\text { information in the past }\end{array}$ & & & & & \\
\hline $\begin{array}{l}\text { I would like climate or weather } \\
\text { forecasts to inform the services I } \\
\text { provide }\end{array}$ & & & & & \\
\hline $\begin{array}{l}\text { Extreme weather events in recent } \\
\text { years have affected the long-term } \\
\text { management goals of producers in } \\
\text { my service area }\end{array}$ & & & & & \\
\hline $\begin{array}{l}\text { Extension staff, crop advisors, and } \\
\text { formal or informal advisors involved } \\
\text { in agriculture often consult with me }\end{array}$ & & & & & \\
\hline $\begin{array}{l}\text { Weather forecasts and information } \\
\text { are not available when I need them } \\
\text { for the services I provide }\end{array}$ & & & & & \\
\hline $\begin{array}{l}\text { I am confident in my ability to apply } \\
\text { weather forecasts and information } \\
\text { to the services I provide }\end{array}$ & & & & & \\
\hline
\end{tabular}


In the past, inaccurate weather information has negatively affected the quality of the services I provide

Producers use climate information when making farm-related decisions

I believe there is an increased need for FSA's programs in my service area due to changing weather patterns

Farms in my service area that historically have not had an interest or need for FSA's programs are or will become more vulnerable moving forward. 


\begin{tabular}{|c|c|c|c|c|}
\hline $\begin{array}{l}\text { Some producers have experienced the } \\
\text { following adverse events or conditions } \\
\text { in the past few years. To what degree } \\
\text { do you think these conditions will } \\
\text { impact agricultural production in your } \\
\text { service area in the future?* }\end{array}$ & $\begin{array}{c}\text { Not } \\
\text { concerned }\end{array}$ & $\begin{array}{c}\text { Slightly } \\
\text { concerned }\end{array}$ & Concerned & $\begin{array}{c}\text { Very } \\
\text { concerned }\end{array}$ \\
\hline \multicolumn{5}{|l|}{ Increased flooding } \\
\hline \multicolumn{5}{|l|}{ Excessive moisture } \\
\hline \multicolumn{5}{|l|}{ Longer dry periods and drought } \\
\hline \multicolumn{5}{|l|}{ Increased weed pressure } \\
\hline \multicolumn{5}{|l|}{ Increased insect pressure } \\
\hline \multicolumn{5}{|l|}{ Higher incidence of crop disease } \\
\hline \multicolumn{5}{|l|}{ More frequent extreme rain events } \\
\hline \multicolumn{5}{|l|}{$\begin{array}{l}\text { Increases in saturated soils and } \\
\text { ponded water }\end{array}$} \\
\hline \multicolumn{5}{|l|}{ Increased heat stress on crops } \\
\hline \multicolumn{5}{|l|}{ Increased incidence of crop stress or } \\
\hline \multicolumn{5}{|l|}{ Increased heat stress on livestock } \\
\hline \multicolumn{5}{|l|}{ Increased loss of nutrients into } \\
\hline $\begin{array}{l}\text { Increased amounts of animal manure } \\
\text { into waterways }\end{array}$ & & & & \\
\hline
\end{tabular}




Increased soil erosion
Increased incidence of wind or excess
wind
Increased incidence of tornados
Increased incidence of hurricanes or
tropical depressions
Increased incidence of hail


There is increasing discussion about climate change and its potential impacts. Please select the statement that best reflects your beliefs about climate change.*

Climate change is occurring, and it is caused mostly by natural changes in the environment

Climate change is occurring, and it is caused mostly by human activities

Climate change is occurring, and it is caused equally by natural changes in the environment and human activities

Climate change is not occurring

There is not sufficient evidence to know with certainty whether climate change is occurring or not

Given what you believe to be true about the potential impacts of climate change on agriculture in the United States, to what degree do you agree with the following statements?* 
Strongly

disagree
Disagree
Neither agree

nor disagree
Agree

Strongly

agree

I have the knowledge to help producers deal with any weather-related threats to the viability of their farm operations

Climate change is not a big issue because human ingenuity will enable producers to adapt to changes

Producers should take additional steps to protect their operations from increased weather variability

In my current role, I should help producers to prepare for increased weather variability

It is important for producers to adapt to climate change to ensure the long-term success of U.S. agriculture

Producers should do more to reduce greenhouse gas emissions from their farm operations 
Please indicate your highest level of education.

Some formal education, less than high-school

High school graduate/ GED

Some college

2-year college degree or technical degree

4-year college degree

Graduate degree (MS, MD, PhD etc.)

Prefer not to answer

In what state or territory is your duty station located?

Respondents are presented with list of 50 states and US territories

In what county is your duty station located? 
Which of the following FSA program areas would you estimate has the highest level of producer participation in your service area (by number of producers)?

Price support (MPP dairy, MAL, LFP, RTCP, Cotton Ginning Cost Share, etc.)

Farm Loans (Farm Storage Facility Loans, Farm Operating Loans, Microloans, Emergency Loans, etc.)

Revenue loss coverage (ARC, PLC)

Risk Management/disaster assistance (NAP, ELAP, TAP, LFP, LIP, etc.)

Energy programs (BCAP, etc.)

Conservation programs/practices (CRP, CREP, GRP, etc.)

Please check the three programs or task areas in which you spend the majority of your time.

Price support (MPP dairy, MAL, LFP, RTCP, Cotton Ginning Cost Share, etc.)

Farm Loans (Farm Storage Facility Loans, Farm Operating Loans, Microloans, Emergency Loans, etc.)

Revenue loss coverage (ARC, PLC)

Risk Management/disaster assistance (NAP, ELAP, TAP, LFP, LIP, etc.)

Energy programs (BCAP, etc.)

Conservation programs/practices

Outreach and education

Compliance, crop reporting, acreage reporting, business partner, farm records, etc.

Loss adjustment/measurement services

Geographic Information Systems (GIS) and Imagery 
Information Technology (IT)

Administrative (banking, file management, office operations, etc.)

In what year were you born?

For how many years have you worked for FSA?

For how many years have you worked for the USDA? 
Which of the following describes your work jurisdiction?

I work in a county office

I work in a state office

Other

If the respondent indicates working at a county level: What is your current position at FSA?

Program Technician

Key or Lead Program Technician

County Executive Director

Administrative Technician

County Office Trainee (COT)

Farm Loan Manager

Farm Loan Officer

Farm Loan Officer Trainee (FLOT)

Farm Loan Analyst

Other (please write in) 
If the respondent indicates working at a state level: What is your current position at FSA?

GIS Specialist

Administrative Officer

Agricultural Program Specialist

Farm Program Chief

Farm Loan Program Chief

Program Technician

County Operations Reviewer

Public Affairs Specialist

Other

If the respondent indicates working in an "other" type of office: What is your current position (job title) at FSA?

What is your gender identity?

Male

Female

Prefer not to answer 
What is your race?

American Indian or Alaska Native

Asian

Black or African American

Native Hawaiian or Other Pacific Islander

White

Prefer not to answer

What is your ethnicity?

Hispanic or Latino

Not Hispanic or Latino

Prefer not to answer

If there is anything else you want to share with us on this topic, please type it into the text box below. 
Would you like to receive a summary report of the research findings? If you choose to click yes, we will not associate your email address with any answers you gave to survey questions. Your answers will remain confidential.

Yes (please write in your email address)

No 


\section{Appendix C: NRCS Survey}

\section{NRCS Survey}

Thank you for taking time to answer the following questions about your role as a natural resource conservation service provider and your thoughts about weather and climate related risk. Your answers will be used to improve USDA program administration, as well as contribute to important research on natural resource management and adapting to a changing climate. The survey should take you approximately 20 minutes to complete.

Throughout the course of the survey, you will note that there are questions about both weather and climate, which are two separate but connected concepts. Weather refers to changing conditions of the earth's atmosphere over short periods of time (e.g., minutes to months) and climate refers to trends in the earth's atmosphere over relatively longer periods of time (e.g., decades to centuries).

通

Indicates that the question, sub-question, or answer choice is visible to respondents who report working with any land managers in their daily activities (Farmer by lain Hector from the Noun Project)

Indicates that the question, sub-question, or answer choice is visible to respondents who report working with farmers in their daily activities (Corn by Anniken \& Andreas from Noun Project)

全 Indicates that the question, sub-question, or answer choice is visible to respondents who report working with forest landowners in their daily activities (Tree by Deemak Daksina S from Noun Project)

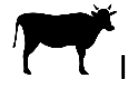
ndicates that the question, sub-question, or answer choice is visible to respondents who report working with ranchers in their daily activities (Cow by Bakunetsu Kaito from Noun Project)

Questions and sub-questions without an icon are visible to all respondents

* Indicates a question taken or adapted from Prokopy et al. 2013 
Please indicate whether you work with the following land managers in your daily activities (select all that apply):

Farmers

Forest landowners

Ranchers

I do not work with land managers in my daily activities

早

WIn what sector do you spend the majority of your time as an NRCS employee?

Agriculture

Forestry

Ranching 
Which of the following categories best describes the size of farm/ranch operation you typically work with?

1-49 Acres

50-99 Acres

100-259 Acres

260-999 Acres

1,000-1,999 Acres

2,000-4,999 Acres

5,000-9,999 Acres

10,000+ Acres

Not applicable

17

Which of the following farm/ranch size (in gross annual sales) do you estimate has the highest participation rate in NRCS programs in your state (if you work for a State Office), area (if you work in an Area Office), or County (if you work for a County Office)?

Small farms - Low sales (gross

Small farms - Moderate sales (gross $\$ 150,000-349,999)$

Midsize farms (gross sales between $\$ 350,000-\$ 999,999)$

Large farms (gross sales $\$ 1,000,000$ or more)

Don't know/Prefer not to answer 
全 typically work with?

1-9 Acres

10-19 Acres

20-49 Acres

50-99 Acres

100-199 Acres

200-499 Acres

500-999 Acres

$1000+$ Acres

Not applicable

高

What do your customers typically grow/produce? (check all that apply)

Grains, oilseeds, dry beans, and dry peas

Other row crops (e.g. tobacco, cotton and cottonseed)

Vegetables, melons, potatoes, and sweet potatoes

漕

虂 woody crops, and other specialty crops

$\overbrace{\perp}$ Forest/timber products 
漕

㗕 Aquaculture

Pairy/milk from cows

Cattle and calves

Hay, forages, or silages

馔

榑

借

sheep, goats, wool, mohair, and milk other than cow

Other (write in)

In addition to working for NRCS, do you operate, own, or have a financial stake in a farm or ranch?

Yes

No

Prefer not to answer 
If respondent answered "yes" to previous question: Please indicate the average size of your farm(s) or ranch(es).

Small farms (gross sales less than $\$ 350,000$ )

Midsize farms (gross sales between $\$ 350,000-\$ 999,999)$

Large farms (gross sales $\$ 1,000,000$ or more)

Prefer not to answer

In addition to working for NRCS, do you operate, own, or have a financial stake in forest land?
Yes
No
Prefer not to answer

If respondent answered "yes" to previous question: Which of the following best describes your forestry operation?

Small forest landowner (average harvest under 2 million board feet/year)

Industrial forest landowner (average harvest over 2 million board feet/year)

Prefer not to answer 
Do you consider weather forecasts (daily, weekly, or seasonal) when you discuss the following topic areas with producers, either formally or informally? If you do not work directly with producers, please skip this entire question.*
No, but I

Yes, I would if I had do better information
I don't discuss

No, I these

don't decisions with producers

Crop and/or variety choices
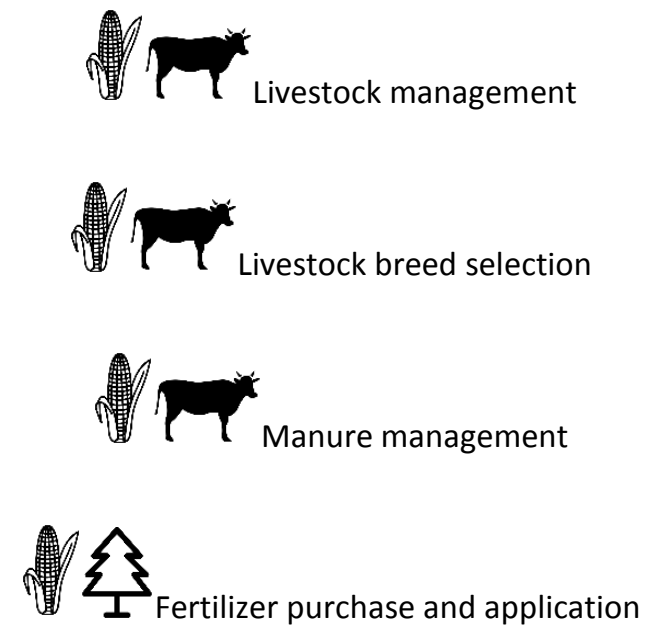

Pesticide purchase and application

$$
\text { Energy/fuel efficiency }
$$
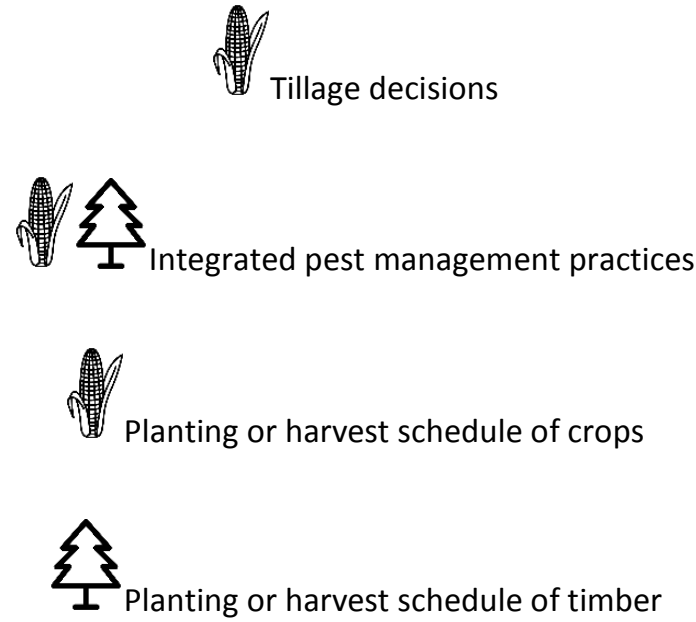

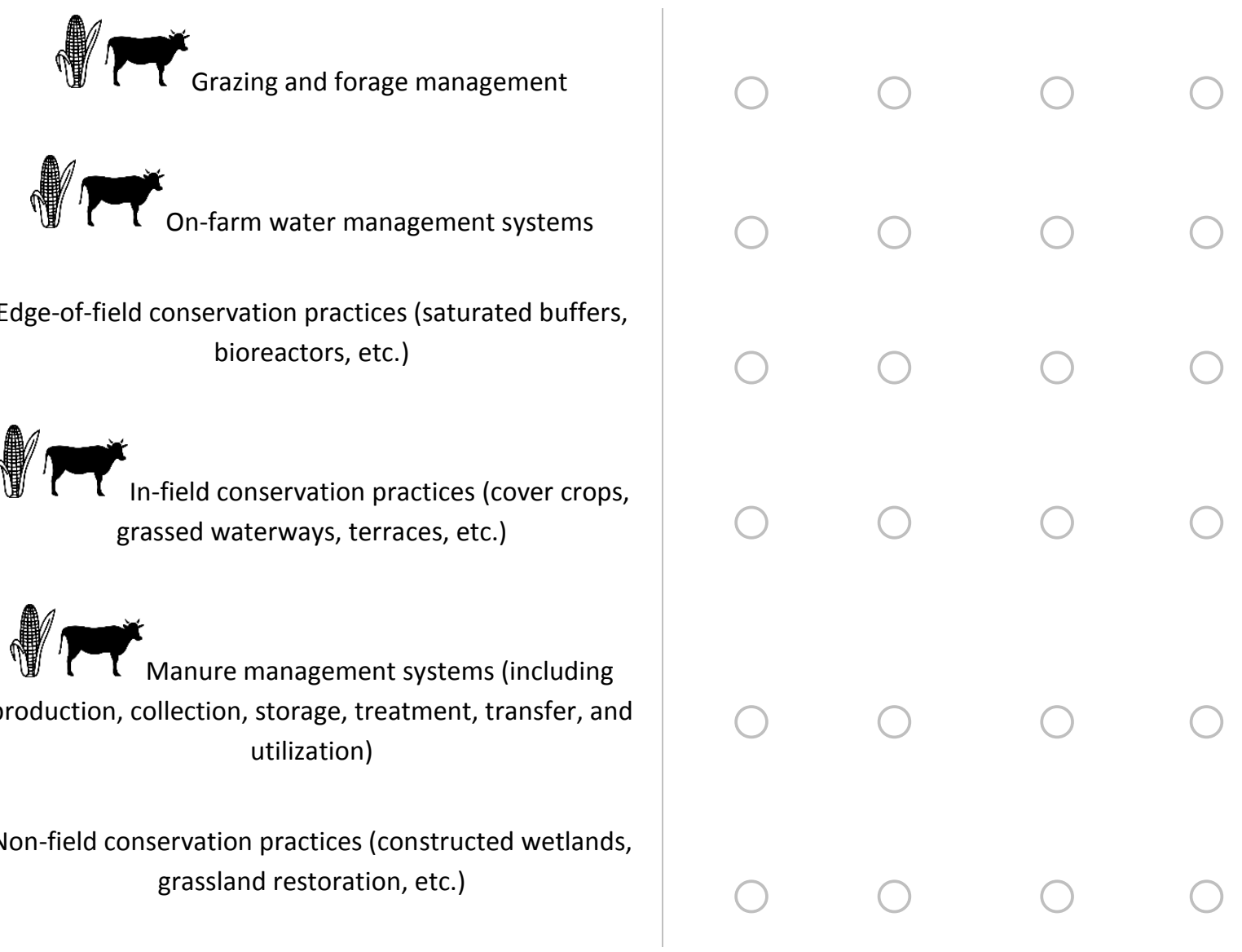
In general, how dependent are you on the following types of weather information when delivering NRCS technical guidance (if you work directly with producers), or in the course of your regular job duties (if you do not work directly with producers)?*

\begin{tabular}{l|l} 
Historical weather \\
trends
\end{tabular}


Do you use any of the following weather-related resources? Note that these resources may be accessible via newsletters, websites, meetings, radio and other sources and they may not

Use Don't use $\quad \begin{gathered}\text { Not familiar } \\ \text { with }\end{gathered}$
have the exact same name listed here.*
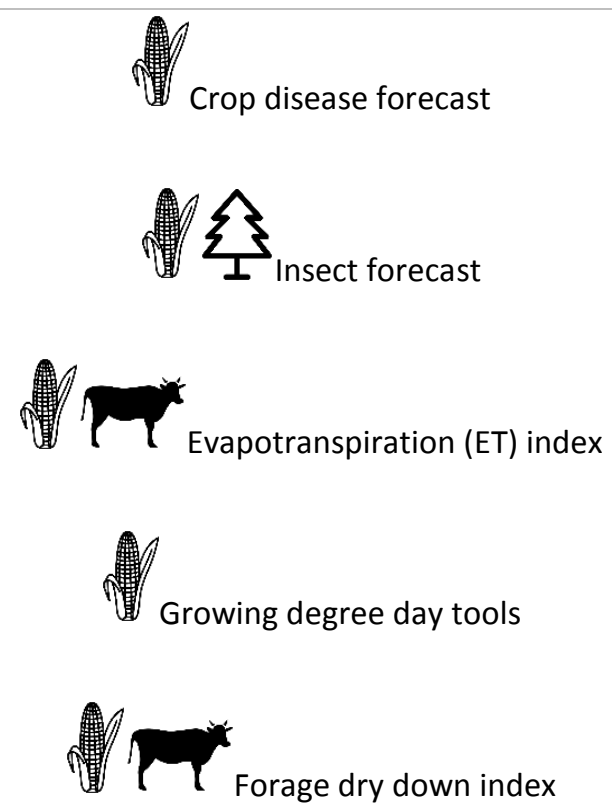

U.S. Drought monitor/outlook

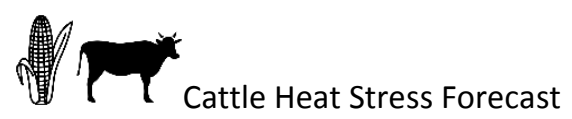

Satellite data/indices of water or soil nitrogen status, precipitation or temperature
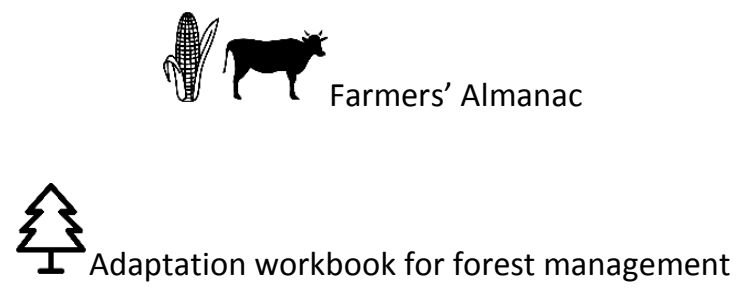

COMET-Farm

USDA Climate Hubs Tool Shed 
Other (write-in) 
Extreme weather events in recent years have affected the long-term management goals of producers in my service area

Extension staff, crop advisors, and formal or informal advisors involved in natural resource management often consult with me

Weather forecasts and information are not available when I need them for the services I provide

I am confident in my ability to apply weather forecasts and information to the services I provide

In the past, inaccurate weather information has negatively affected the quality of the services I provide

In the past, accurate weather information has positively affected the quality of the services that I provide

Producers use climate information when making management-related decisions

I believe there is an increased need for NRCS programs in my service area due to changing weather patterns

Producers in my service area that historically have not had an interest or need for NRCS programs are or will become more vulnerable moving forward 
Some producers have experienced the following adverse events or conditions in the past few years. To what degree do you think these conditions will impact agricultural and forestry production in your service area in the future?*

Increased flooding

Excessive moisture

Longer dry periods and drought

Increased weed pressure

Increased pressure from insect species

Increased pressure from plant species

Increased pressure from animal species

Higher incidence of crop/plant disease

$\sum 5$ $\perp$ Higher incidence of tree pathogens

Higher incidence of wildfire

More frequent extreme rains

Increases in saturated soils and ponded water<smiles>C1CCC(C2CC2)C1</smiles>

Increased heat stress on crops

\begin{tabular}{|c|c|c|}
\hline $\begin{array}{c}\text { Not } \\
\text { concerned }\end{array}$ & $\begin{array}{c}\text { Slightly } \\
\text { concerned }\end{array}$ & Concerned \\
\hline
\end{tabular}




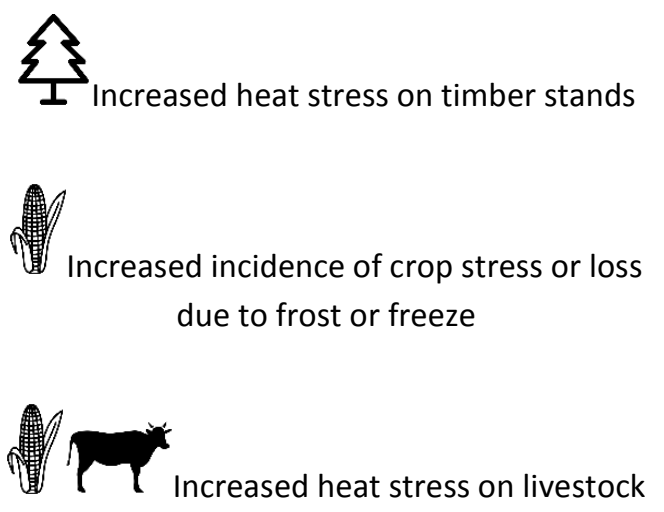

Increased loss of nutrients into waterways

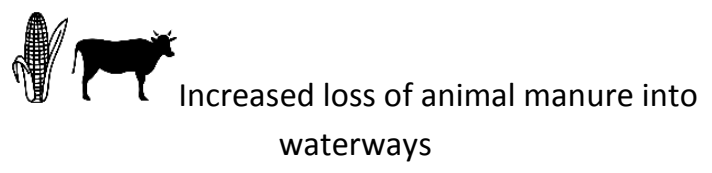

Increased soil erosion

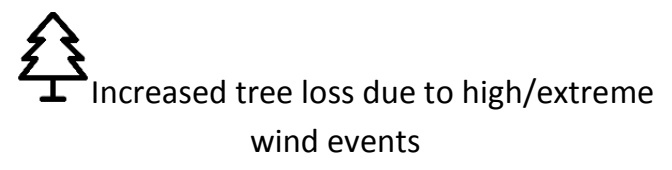

Increased wildlife herbivory or predation

Increased incidence of hail events

Increased incidence of tornado events

Increased incidences of hurricanes/tropical depressions

Increased incidences of wind storms

Reduced snowpack/ frozen ground impacting harvest activities 
There is increasing discussion about climate change and its potential impacts. Please select the statement that best reflects your beliefs about climate change.*

Climate change is occurring, and it is caused mostly by natural changes in the environment

Climate change is occurring, and it is caused mostly by human activities

Climate change is occurring, and it is caused equally by natural changes in the environment and human activities

\section{Climate change is not occurring}

There is not sufficient evidence to know with certainty whether climate change is occurring or not 
Given what you believe to be true about the potential impacts of climate change on natural resource management (farms, forests, rangelands) in the United States, to what degree do you agree or disagree with the following statements? *

I have the knowledge and technical skill to help producers deal with any weather-related threats to the viability of their operation

There's too much uncertainty about the impacts of climate change to justify advising or discussing with producers any changes to their management practices and strategies

Climate change is not a big issue because human ingenuity will enable us to adapt to changes

I am concerned that available best management practice technologies are not effective enough to protect the producers I advise from the impacts of climate change

Producers should take additional steps to protect their land from increased weather variability

Assisting producers to prepare for increased weather variability is a part of my job

It is important for producers to adapt to climate change to ensure the long-term success of U.S. agriculture

全 climate change to ensure the long-term success of U.S. forestry

$\begin{array}{ccc}\text { Strongly } & \begin{array}{c}\text { Neither } \\ \text { disagree }\end{array} \text { Disagree } & \begin{array}{c}\text { Strongly } \\ \text { disagree }\end{array}\end{array}$




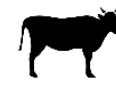

It is important for producers to adapt to climate change to ensure the long-term success of U.S. rangeland

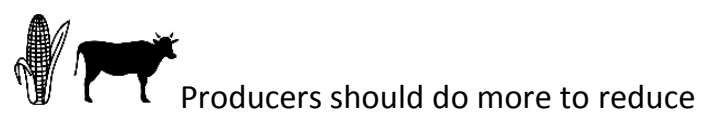
greenhouse gas emissions from their farm operations

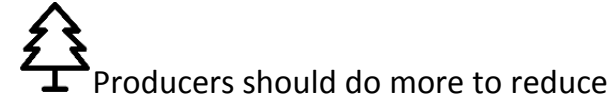
greenhouse gas emissions from their forestry operations

Please indicate your highest level of education.

Some formal education, less than high-school

High school graduate/ GED

Some college

2-year college degree or technical degree

4-year college degree

Graduate degree (MS, MD, PhD etc.) 
If the answer to the previous question indicated a 2-year, 4-year, or graduate degree: In what general subject area is your degree?

Natural Resource Management

Forestry

Agronomy

Animal Science

Other (write in)

In what state or territory is your duty station located?

Respondents are presented with list of 50 states and US territories

Which of the following program areas would you estimate has the highest level of participation among producers in your service area based on total number of participants?

Agriculture Management Assistance (AMA)

Conservation Easement Programs (ACEP, GRP, HFRP, WRP, etc.)

Conservation Stewardship Programs (CSTP, CSP, etc.)

Conservation Technical Assistance (CTA, GLCl, Soils, NRI, etc.)

Conservation Reserve Program (CRP)

Environmental Quality Incentives Program (EQIP) 
Please check the three programs areas in which you spend the majority of your time:

Agriculture Management Assistance (AMA)

Conservation Easement Programs (ACEP, GRP, FRPP, HFRP, WRP, etc.)

Conservation Innovation Grants (CIG)

Conservation Stewardship Programs (CSTP, CSP, etc.)

Conservation Technical Assistance (CTA, GLCl/CPGL, Soils, NRI, etc.)

Conservation Reserve Program (CRP)

Environmental Quality Incentives Program (EQIP, WHIP)

Landscape Planning (EWP, PL566 Watershed Operations, Planning, Rehabilitation)

Please check the top three program initiatives, projects, and/or activities in which you spend the majority of your time:

Administrative (accounting, file management, office operations, information technology, etc.)

Conservation Compliance (Determinations for eligibility or compliance)

Landscape-Level Projects (RCPP projects, Chesapeake Bay, Everglades, Migratory Birds, Prairie Pothole, Targeted Forestry, WLFW, Sage Grouse, Longleaf Pine, Lesser Prairie-Chicken, Monarchs, Honey Bees, etc.)

Technical Services and Products (Technology Transfer, Resource Inventory and Assessment (CEAP, NRI, SNOTEL, Soil Survey); Practice Design, layout and evaluation; Site-Specific, Area, 
Community, and or Watershed level Plan Development, Educational and Demonstration Projects, International Projects)

Training, Quality Assurance, Supervision, Management (Spot Checks, Program Reviews, Appeals, Mediation, Conservation Compliance Reviews, Training, Supervision, Management)

Water-based Initiatives (NWQI, MRBI, Ogallala Aquifer, Driftless Area, etc.)

General Farm Bill program delivery other than initiatives (planning, contracting, implementing, certifying, etc.)

In what year were you born?

For how many years have you worked for NRCS?

For how many years have you worked for USDA? 
Where is your current position at NRCS located?

NRCS Service Center

Area Office

Regional Office/Technology Support Center

State Office

Other (write in) 
What is your current position at NRCS?

Soil Conservation/Engineering Technician

Soil Conservationist

Resource Conservationist

Range Conservationist

Soil Scientist

Engineer

Forester

Wildlife Biologist

Agronomist

Area Conservationists

District Conservationists

Assistant State Conservationist- Field Operations

Assistant State Conservationist- Program

State Resource Conservationist

State Conservationist

Education/Outreach Specialist

Stewardship Coordinator

Administrative Staff

Regional Scientist (specify): 
Other (write-in):

Prefer not to answer

What is your gender identity?
Male
Female
Prefer not to answer

What is your race?
American Indian or Alaska Native
Asian
Black or African American
Native Hawaiian or Other Pacific Islander
White
Other (write-in)
Prefer not to answer 
What is your ethnicity?

Hispanic or Latino

Not-Hispanic or Latino

Other (write-in)

Prefer not to answer

Would you like to receive a summary report of the research findings? If you choose to click yes, we will not associate your email address with any answers you gave to survey questions. Your answers will remain confidential.

Yes (write in email address)

No 